\title{
Effectiveness of plants and green infrastructure utilization in ambient particulate matter removal
}

\author{
Katarzyna Wróblewska ${ }^{1,2^{*}}$ [C and Byoung Ryong Jeong $2,3,4$
}

\begin{abstract}
Air pollution is regarded as an increasingly threatening, major environmental risk for human health. Seven million deaths are attributed to air pollution each year, $91 \%$ of which is due to particulate matter. Vegetation is a xenobiotic means of removing particulate matter. This review presents the mechanisms of PM capture by plants and factors that influence PM reduction in the atmosphere. Vegetation is ubiquitously approved as a PM removal solution in cities, taking various forms of green infrastructure. This review also refers to the effectiveness of plant exploitation in Gl: trees, grasslands, green roofs, living walls, water reservoirs, and urban farming. Finally, methods of increasing the PM removal by plants, such as species selection, biodiversity increase, PAH-degrading phyllospheric endophytes, transgenic plants and microorganisms, are presented.
\end{abstract}

Keywords: PM capture, Vegetation, Green roofs, Living walls, Urban farming

\section{Background}

Human activity plays a central role distort many of Earth's regular functions. Intensification of these changes and their impact on nature and humans has led to Paul Crutzen to name the present epoch "Anthropocene" [1]. Its beginning is usually related to the Industrial Revolution in the eighteenth and nineteenth centuries when energy-consuming processes, like mechanization or reactive nitrogen syntheses, have started [2], which brought about intensive fossil fuel mining and coal combustion, accompanied by increasing population and urbanization. This resulted in emissions of black smoke, i.e., a composition of carbonaceous particles as major components of the airborne particulate matter (PM), carbon dioxide $\left(\mathrm{CO}_{2}\right)$, sulfur dioxide $\left(\mathrm{SO}_{2}\right)$, nitrogen oxides $\left(\mathrm{NO}_{\mathrm{x}}\right)$, and water vapor. PM react with water to form new particles with different properties and lead to periodic smog,

\footnotetext{
*Correspondence: katarzyna.wroblewska@upwr.edu.pl

1 Department of Horticulture, Wrocław University of Environmental and Life Sciences, Wrocław, Poland

Full list of author information is available at the end of the article
}

which has been well-documented in London in 1952, which led to increased mortality from pneumonia and bronchitis [3]. Alongside the development of agriculture, increased methane $\left(\mathrm{CH}_{4}\right)$ contents has been observed [4]. Moreover, $\mathrm{CO}_{2}, \mathrm{CH}_{4}, \mathrm{~N}_{2} \mathrm{O}$, and vapor present in the air, have been observed to be responsible for the depletion of the stratospheric ozone layer, which results in the greenhouse effect and global warming, which is one of the greatest ecological concerns of the contemporary world.

Further rapid increases in air pollution and greenhouse effects have been noted since the 1950s, brought about by the explosive population growth, technological development, and prolonged life expectancy. The Great Acceleration, as it is called, is also a period of unprecedented rise of consumption, overusing natural resources and over-producing harmful byproducts. With the switch from coal to oil combustion, the concentration of black smoke has dropped [3], but new contaminants have been added to the atmosphere. Their presence is connected with industrial combustion, automobile transport, as well as the accelerated development of the chemical and pharmaceutical industries [5]. Other sources of air 
pollution include power plants, waste (especially combusted waste), as well as household heating, cooking and lighting [6]. They 'enrich' the air of metals, metalloids, hydrocarbons (HCs), including chlorofluorocarbons (CFCs), hydrofluorocarbons (HFCs), halons containing $\mathrm{Br}$, volatile organic compounds (VOCs), and others. $\mathrm{Cl}, \mathrm{F}$ and $\mathrm{Br}$ ions released from $\mathrm{HCs}$ and halons catalyze thousands of reactions with $\mathrm{O}_{3}$ in the stratosphere, accelerating the greenhouse effect [7].

All the previously mentioned contaminants form mixtures that pose danger to human health. In fact, air pollution is regarded as the main environmental risk for human health and is a rising concern [8]. After tobacco smoking, air pollution is the second most common form of noncommunicable diseases. Globally, air pollution accounts for 7 million premature deaths every year, 91\% of which is caused by particulate matter [9]. The most ubiquitous death causes include stroke, heart disease, genotoxic effects such as leukaemia, lymphomas, lung cancer, and respiratory diseases such as asthma. Higher morbidity embraces also other cardiovascular and respiratory problems, but also kidney, intestinal, nervous (including depression, dementia and Alzheimer disease) disorders, allergy, and inflammation through the generation of reactive oxygen species and oxidative stress $[10,11]$. All of them lead either to deterioration of wellbeing, or vast economic costs. In fact, economic costs are far beyond the medical problems related to pollution. Among others, dust, impaired visibility, air traffic distortions, odor, decreased agricultural yield, and degraded quality of products (e.g. incomplete ripening of fruits) due to reduced solar irradiation are mentioned as economic costs related to air pollution. Indirect costs connected with climate change, like extreme heat incidents, increased UV radiation, decreased or immense precipitation, water availability, floods and desertification bringing about further health problems, damage of property and infrastructure, and reduction of agricultural production are also associated with air pollution. Another concern is an accelerated sea level rise which threatens low-lying islands and coastal zones [7, 12, 13]. The ecological costs related to air pollution is difficult to evaluate.

According to the WHO [14], 91\% of the world's population breathe air that's polluted beyond safe levels, which is $10 \mu \mathrm{g} \mathrm{m}^{-3}$ annually and $25 \mu \mathrm{g} \mathrm{m}^{-3}$ daily for $\mathrm{PM}_{2.5}$, and $20 \mu \mathrm{g} \mathrm{m}^{-3}$ annually and $50 \mu \mathrm{g} \mathrm{m}^{-3}$ daily for $\mathrm{PM}_{10}$ [14]. The very fatal phenomenon of air pollution is its relationship with the economic development of a country following the Kuznetz curve [15, 16], which means that countries with lower income, which are often overpopulated and suffering from inadequate health care system, experience a higher level of air contaminants. Among numerous ways of air pollution mitigation, including political policies and technological methods focusing on reduction of emissions (by reduction of energy consumption and increasing urban sustainability) [17], programs employing massive tree and shrub planting are recommended [14, 18] as they are considered cheap, eco-friendly and multi-beneficial [19]. It also brings about positive side effects connected with climate change mitigation. Cities based on garden-city concepts such as Putrajaya, Malaysia, or cities with an intensively developing green infrastructure like Stuttgart, Germany, succeed in the attenuation of urban heat islands [20]. Studies from Asian cities like Kuala Lumpur, Singapore, and Hong Kong demonstrate that vegetation may reduce air temperature by as much as $4{ }^{\circ} \mathrm{C}[21]$.

According to Crippa et al. [22], in 2012 people emitted about $103 \mathrm{Mt}$ of $\mathrm{SO}_{2}, 562 \mathrm{Mt}$ of $\mathrm{CO}, 122 \mathrm{Mt}$ of $\mathrm{NO}_{\mathrm{x}}$, $170 \mathrm{Mt}$ of NMVOC, $59 \mathrm{Mt}$ of $\mathrm{NH}_{3}, 65 \mathrm{Mt}$ of $\mathrm{PM}_{10}$ and $41 \mathrm{Mt}$ of $\mathrm{PM}_{2.5}$ globally. How much of these residues can be removed and retained by vegetation? Is it possible to increase this amount and substantially improve the air quality? The purpose of this paper is to present a critical review on the possibilities of how plant utilization can effectively clean the air of the most hazardous contaminants, PM. In this paper we try to estimate the potential of plants to internally accumulate pollutants. We also consider factors affecting their effectiveness in order to find the conditions that should be fulfilled to improve the effectiveness of vegetation in air bioremediation (Fig. 1).

\section{Discussion}

\section{The types of air pollutants, their origins, and risks} Physical stages of air contaminants: gases and aerosols

Gaseous pollutants Within the main gaseous pollutants $\mathrm{CO}, \mathrm{NO}_{x}, \mathrm{SO}_{2}$, total volatile organic compounds (VOCs), and $\mathrm{NH}_{3}$ are mentioned. Most gaseous pollutants are produced by human activity: road transport $\left(\mathrm{NO}_{\mathrm{x}}\right)$, fuel combustion (CO, $\mathrm{SO}_{2}$ and VOCs), industry $\left(\mathrm{SO}_{2}\right)$, agriculture $\left(\mathrm{NH}_{3}\right)$, off-road transportation, and the residential activities. $\mathrm{SO}_{2}$ and $\mathrm{NO}_{\mathrm{x}}$ react with water in the atmosphere and generate acid precipitations. This phenomenon leads to deterioration of human health, degradation of plants, acidification of freshwater, deaths of aquatic animals, and damage of properties (corrosion of metals and weathering of stone buildings and monuments). This was the impetus for numerous policies aiming to lower the $\mathrm{SO}_{2}$ and $\mathrm{NO}_{x}$ emissions and gradually reduce global $\mathrm{SO}_{2}$ emissions since the 1980s. Contrary to this, global $\mathrm{NO}_{\mathrm{x}}$ emissions are growing, although the trend varies among countries. The growing emissions in Asia, South America, Middle East and Africa contrast with the trend in Europe, where emissions are decreasing [23].

Volatile organic compounds (VOCs) are a group of miscellaneous compounds with a high vapor pressure due 


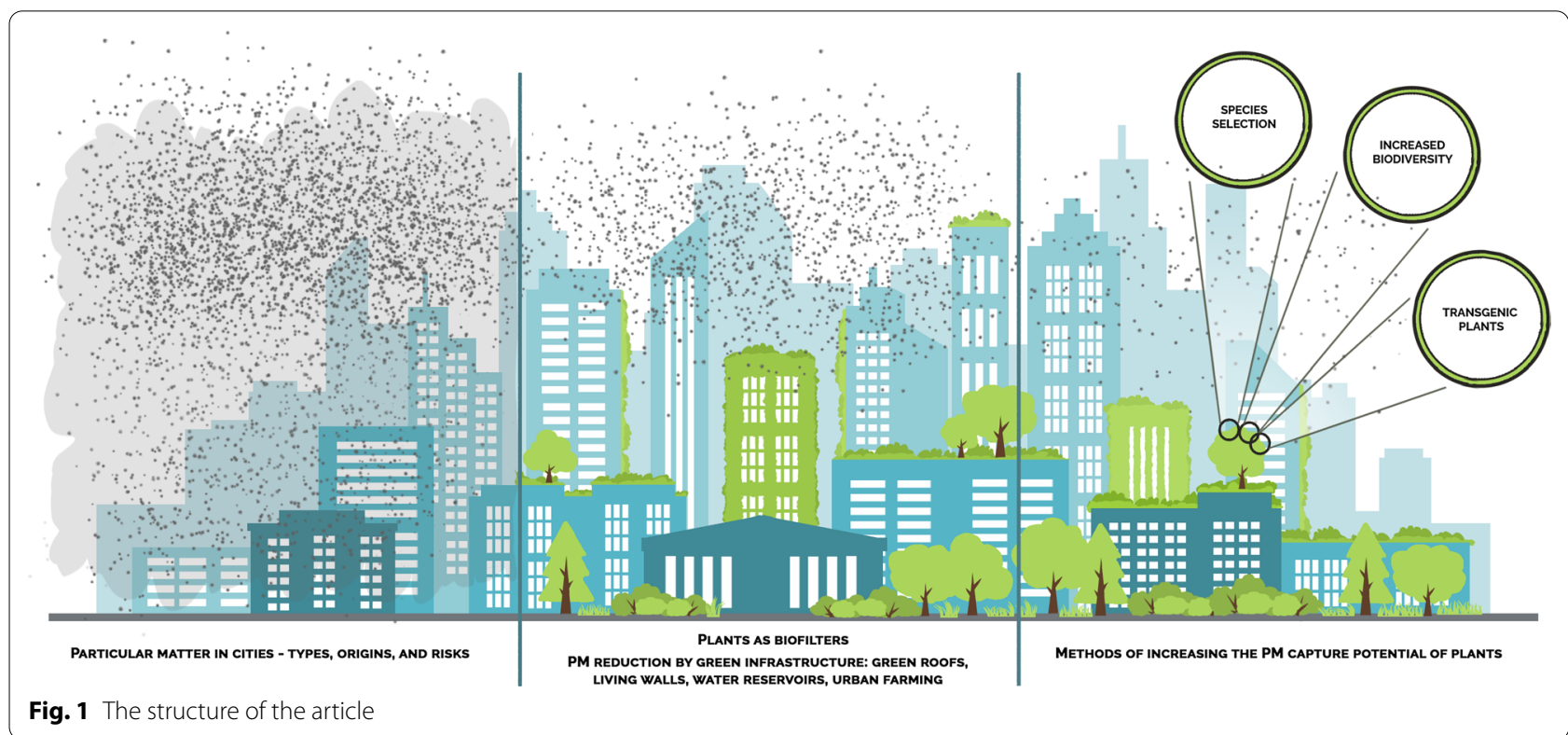

to a low boiling point within the range of $50-260{ }^{\circ} \mathrm{C}$. Most VOCs are volatile at room temperature. VOCs include acetone, aliphatic hydrocarbons, aromatic hydrocarbons (benzene, toluene, ethylbenzene, xylenes and 1,2,4-trimethylbenzene), polycyclic aromatic hydrocarbons (PAHs), chlorinated compounds, and terpenes. They are a source of various scents and odors, and irritate the human skin and/or the respiratory system. They can cause cancer (i.e. benzene, ethylbenzene, tetrachloromethane, and trichloroethylene), allergy, and immune system impairments [24]. They are ubiquitous as they originate from different chemical products of everyday life: construction materials, paints, solvents, cleaning products, cosmetics, and others. The environmental risks posed by VOCs are based on their photochemical reactivity with anthropogenic $\mathrm{NO}_{\mathrm{x}}$, which leads to the formation of ozone, secondary organic aerosols (SOA) and atmospheric oxidants (e.g. peroxyacil nitrates, aldehydes, ketones, hydrogen peroxide) [25]. Apart from anthropogenic sources (AVOCs), VOCs are also generated from plants and other organisms (BVOCs). Annual global VOC emissions are estimated to total about 100 $\mathrm{Tg} C$, out of which the share of BVOCs is calculated to be about $90 \%$ [26].

Aerosols Aerosols consist of liquid and solid particles (particular matter, PM) suspended in the air, and has a diameter between 0.001 and $100 \mu \mathrm{m}$. They are regarded as an equivalent to the historic black smoke, which now also refers to one of the methods of its measurement, i.e. its optical absorption ('blackness') [27]. PM molecules have different origins and diverse chemical properties. It con- sists mainly of black carbon dust, water-soluble ions (sulfates, nitrates, ammonia, chlorides), metals and organic pollutants, where some compounds are highly toxic to living organisms. Apart from chemical character, their size and surface area are key factors determining their malice. Usually, two categories of PM are monitored according to their aerodynamic diameter: $\mathrm{PM}_{10}$ and $\mathrm{PM}_{2.5}$. Their size determines the depth of deposition in the respiratory system [28]. Coarse particles $\left(\mathrm{PM}_{10}\right)$, with a diameter of $10 \mu \mathrm{m}$ or less reach mainly the upper part of the respiratory system and can be removed by natural defense mechanisms. Fine particles $\left(\mathrm{PM}_{2.5}\right)$, with the a diameter smaller than $2.5 \mu \mathrm{m}$, are inhaled into the lungs. $\mathrm{PM}_{2.5}$ is more hazardous to humans because of their greater surface area relative to their volume [29]. What is more, toxic polycyclic aromatic hydrocarbons (PAHs) are found within $\mathrm{PM}_{2.5}$, including the highly carcinogenic benzo(a) pyrene [30]. Within $\mathrm{PM}_{2.5}$, ultrafine particles, with aerodynamic diameters below $0.1 \mu \mathrm{m}$ are also distinguished. These particles can cross the border of pulmonary vesicles and get to the blood. As they can behave like gases and enter organisms via diffusion, they can be absorbed also through ingestion, or through the skin, thus interfering with the functioning of different tissues and organs [31, 32]. Much of $\mathrm{PM}_{2.5}$ originates from fuel combustion and traffic. Its concentration in the air is less locally diversified as it can be suspended in the air for a longer time and transported with wind over long distances [33]. They contain several groups of compounds:

Carbonaceous materials Due to their origin of ubiquitous combustion sources, carbon particles are the most numerous in urban PM. The mass of carbonaceous 
material (total C, TC) account for up to $50-70 \%$ of $\mathrm{PM}_{0.1}$ [34]. Carbonaceous materials can be classified into two classes: black or elemental carbon $(\mathrm{BC}, \mathrm{EC})$ with a graphite structure, which is emitted directly from combustion, and organic carbon $(\mathrm{OC})$, which contain different organic compounds, such as hydrocarbons.

Persistent organic pollutants (POPs) contain toxic chemicals which accumulate in organisms and the environment. As their half-life can be decades, they remain in the environment for a long time and can be transported over long distances; they have thus become a global concern and the motivation for the Stockholm Convention in 2001. According to the Convention, production of 12 chemicals, named the 'DirtyDozen'-aldrin, chlordane, DDT, dieldrin, dioxins, endrin, furans, heptachlor, hexachlorobenzene, PCBs, and toxaphene-are especially hazardous to life and the environment, and their emissions were regulated [35]. 16 other chemicals were added to the list in 2017. POPs can be intentionally (e.g. in chemical industry) or unintentionally produced as byproducts of fuel combustion, waste, biomass, and industry. Among the most common airborne POPs, polycyclic aromatic hydrocarbons (PAHs), polychlorinated biphenyls (PCBs), polychlorinated dibenzo-p-dioxins and dibenzofurans (PCDDs/PCDFs), dioxin-like PCBs (dlPCBs), as well as dichlorodiphenyl trichloroethane and its transformation products (DDTs) are mentioned [36].

Polycyclic aromatic hydrocarbons (PAHs) belong to the most ubiquitous air pollutants. PAHs are a group of hydrocarbons consisting of two or more fused aromatic rings. They can be divided into two classes: low-molecular-weight PAHs with 2 or 3 rings with a volatile character, and high-molecular-weight PAHs which contain 4 or more rings, which are significant constituents of $\mathrm{PM}_{2.5}$. As products of incomplete combustion of hydrocarbons, they are ubiquitous in the environment: they come from transportation, as well as industrial, domestic, agricultural and natural sources. The extraordinary risk of PAHs relates to their high carcinogenicity and toxicity, as well as their persistence due to their hydrophobicity, stability, and high sorption capacity. They are also resistant to biodegradation. The most ubiquitous in air, and the most hazardous is benzo(a)pyrene (BaP). It is usually used as a marker, and the risk coming from other PAHs is evaluated as benzo(a)pyrene equivalent (B(a)Peq) [37].

Heavy metals The presence of metals in the air is one of the major current concerns, both for environmental and health reasons. Most metals and metalloids constitute $\mathrm{PM}_{2.5}$, and those that do not have a diameter smaller than $0.1 \mu \mathrm{m}$. As some of them originate from rock erosion or volcanic eruption, they are ubiquitous in the Earth's crust. Yet, metals from anthropogenic sources, including industrial (metallurgic, electroplating and tannery) and agricultural activities as well as vehicle transportation total to more than 5 times the amount of those released from rocks and soil. Some metals $(\mathrm{Cu}, \mathrm{Ni}, \mathrm{Zn}, \mathrm{Co}, \mathrm{Fe}$ and $\mathrm{Mo}$ ), being a component of enzymes and pigments, are crucial for plant metabolism, but all metals are toxic in high concentrations. They may replace metals in pigments, disturb enzyme activities, and produce reactive oxygen species [38]. $\mathrm{Cd}, \mathrm{Pb}$ and $\mathrm{Hg}$ seem to be the most hazardous for human health. They can have toxic, carcinogenetic, teratogenetic, neorotoxic and mutagenetic effects [39].

\section{Origin of air pollutants}

Contaminants get to the atmosphere in different ways. Primary pollutants are emitted directly to the atmosphere, whereas secondary pollutants develop in the air as a result of chemical or photochemical reactions [40]. Primary pollutants include gases like $\mathrm{CO}, \mathrm{NO}_{\mathrm{x}}$ and VOCs, as well as aerosols, such as black carbon or PAHs. Among the latter, ozone is the most ubiquitous pollutant. Both types may originate not only from human activities, but also from nature.

Anthropogenic sources Anthropogenic sources contain mostly emissions from fuel combustion, traffic components, industry, and agricultural production. Burning solid fuels such as coal, wood, dung, and other biomass releases $\mathrm{NO}_{x}, \mathrm{SO}_{2}, \mathrm{CO}_{2}, \mathrm{CO}$, PAHs, VOCs, and many others depending on the material they originate from. Coal is the most common energy source and is also the most hazardous, especially in residential areas in developing countries. The simple stoves used in those areas cause incomplete combustion, and discharge increased amounts of fine and ultrafine particles: $\mathrm{Cu}, \mathrm{Fe}, \mathrm{S}$, carcinogenic arsenic, silica, fluorine, and metals, e.g. $\mathrm{Pb}, \mathrm{Ni}, \mathrm{Cr}, \mathrm{Hg}$, as well as highly toxic dioxins and dibenzofurans, acrylonitrile, benzo(a)pyrene, methyl bromide, and many others [28]. Combustion is a common method of agricultural land management. It includes burning of living and dead biomass, and deforestation for plant and animal production. The latter, apart from other ecological effects like biodiversity loss, defaunation, and global warming, releases to the atmosphere vast amounts of carbon that's been stored over hundreds of years [41], as well as sulfates, nitrates, ammonia, and sodium chloride. For example, the expansion of agriculture into the tropical forest, commonly in the form of cattle breeding and oil palm plantations, was responsible for more than $2.6 \mathrm{Gt}_{\text {of }} \mathrm{CO}_{2}$ year $^{-1}$ (data from 2010-2014) [42]. After fossil fuel burning, deforestation is considered to be the second biggest source of anthropogenic greenhouse gases (GHGs) [43]. Other ubiquitous source of diverse air pollutants is transport, employing oil charged engines (vehicles, ships, railway and airplanes) 
and industry. Two further sources of PM pollutants, such as military conflicts and fireworks are also of great important and we should make a great effort to avoid them.

Natural sources Natural sources of pollutants comprise of biological and geological sources, like volcanic activity, dust movement (e.g. sand storms), oceanic release, and wildfires. Biological contaminants may also include ubiquitous allergens, like pollen grains, spores, plant fibers, as well as parts of animal hairs and skin. Hairs of some plants, like Heracleum sosnowskyi Manden. suspended in the air may be strongly irritating and lead to photoallergy. Live and dead bacteria, fungi, and viruses are also present. What is more, bacterial endotoxins and mycotoxins may be involved in diverse inflammations. Gaseous pollutants come from lightning, soil emissions, mineralization of organic materials, fresh and marine water, forest fires, and others. The natural gases of major concern include biogenic volatile organic compounds (BVOCs) in prevalent amounts generated by plants, leading to the formation of ozone, SOA, and others [25]. BVOCs play a crucial role in signaling between plants and the environment (for example, as attractants for pollinators and distractions for herbivores) and may include, for example, isoprene, ethylene, fatty acids, and constituents of essential oils. They can be emitted as integral components in plant metabolism, or as a response to stresses $[44,45]$. Constitutive compounds consist of, in majority, isoprene and monoterpenoids. Similarly, stress-induced BVOCs (sBVOCs) include monoterpenes, sesquiterpenes, sesquiterpenoids, benzenoids, and volatile lipoxygenase products (green leaf volatile products). BVOC emissions are positively correlated with the leaf area and stresses, like herbivore attacks, temperature, drought, and ozone content increase [46]. In cities, plants face many stresses like urban heat island (UHI), low humidity, drought, modified soils and pure aeration, as well as air and soil pollution. In such conditions, BVOC emissions rise substantially, up to about 100-1000 times that in non-stressed laboratory conditions [45]. These findings are corroborated by analyses of global BVOC emissions. European studies indicate that BVOC production is much higher in the Mediterranean region than in the northern countries [47]. Together with global warming, a further increase in the stress-induced BVOC production is expected (Sicard et al. 2016). Furthermore, sBVOCs, especially sesquiterpenes and benzenoids, have a greater potential for SOA formation than isoprene and monoterpenes do [45]. Global emissions of BVOCs is estimated to be $1000 \mathrm{Tg}$ in (data from 2000), 50\% of which belongs to isoprene and $30 \%$ to methanol, ethanol, acetaldehyde, acetone, $\alpha$-pinene, $\beta$-pinene, $t$ - $\beta$ ocimene, limonene, ethylene, and propene [48]. This composition varies around the world depending on the climate and plant species. For example $e_{2}$ tropical rainforests, which cover about $18 \%$ of the globe's area, are responsible for $80 \%$ of the global terpenoid emissions and $50 \%$ of other BVOC emissions [48].

\section{Plants as biofilters \\ Mechanisms of pollutant capture and detoxification}

Plant metabolism is based on the gas exchange between plant tissues and the environment. It takes place through the stomata for most species, which exist on the abaxial side of the leaves. The aperture of the stomata reaches 4-10 $\mathrm{nm}$ and depends on several factors, including water availability, temperature, the stage of plant development, and the time of the day. The same factors influence absorption of gas and liquid xenobiotics as stomata are the main route through which they enter the leaf. Ultrafine PM may also get to the plant through these doors. For lipophilic pollutants, like aromatic hydrocarbons, the cuticle is another pathway [49,50]. After entering the leaf, the xenobiotics can be submitted to different processes to protect the organism against contaminant toxicity: excretion, conjugation, followed by compartmentalization or degradation to simple cell metabolites. Conjugation is a predominant and ubiquitous pathway. During this process contaminants are linked to cell compounds such as proteins, saccharides, lignin, amino acids, organic acids, and others [49], forming covalent bonds. This substantially decreases the toxicity of pollutants and allows them to be left in cells for a certain period until the plant enzymatic system is able to further transform them. The other possibility is compartmentalization, where cells remove the conjugates far away from strategic organelles, like nuclei, mitochondria and plastids for long-time storage. This process is thus also called 'storage excretion'. Watersoluble conjugates are stored in vacuoles, while lipophilic ones accumulate in cell walls. Some of them can also be excreted to the extracellular spaces [51].

Contrary to gaseous pollutants, PM is mainly deposited on the leaf surface via wet or dry deposition. Adaxial surface of leaves collects more PM than the abaxial side does. For example, the average particle leaf surface density for adaxial side of Platanus acerifolia (Aiton) Willd. was twice as high as that for the abaxial side $\left(3.4 \times 10^{4}\right.$ particles $\times \mathrm{mm}^{-2}$ to $1.7 \times 10^{4}$ particles $\times \mathrm{mm}^{-2}$, respectively) [52]. In another study, $10-50 \%$ of the adaxial leaf surface area of Ulmus pumila L., Salix babylonica L. and Ginkgo biloba L. was covered by PM, compared to only $3-35 \%$ of the abaxial area [53]. This also impedes PM access to leaves via the stomata. Instead, the PM may be collected on the leaf surfaces or encapsulated in the cuticle. Nevertheless, contaminant accumulation on leaves is only a temporary capture, which ends with the falling of leaves. Then the contaminants transform into soil residues. Due to the longer period of storage (up to 5 years), 
evergreen species are generally more advantageous in air pollution mitigation [54]. Dry deposited particles can be removed from the surface by wind and rain. This is less likely if contaminants are embedded in the cuticle. What is more, some of lipophilic particles immobilized in the cuticle may be transported further into the parenchyma cells, where they are detoxified. It has been observed that hydrophilic contaminants, containing polar compounds and ions, can also penetrate the cuticle, but at far less intensive rates [55].

\section{Factors affecting the efficiency of plant PM capture}

Deposition of air pollutants in plants depends on diverse factors calculated according to the equation below, indicating the factors that influence this process [56]:

$$
\text { Deposited amount }\left(\mathrm{g} \times \mathrm{m}^{-2}\right)=\mathrm{LAI} \times v_{\mathrm{d}} \times C \times t
$$

where LAI refers to the leaf area index; $v_{\mathrm{d}}$ is the deposition velocity, $C$ is the concentration of the pollutant, and $t$ is the time. Deposition velocity is usually calculated as the reciprocal of resistance to deposition, including aerodynamic, boundary and, the most impactful, surface resistance:

$$
v_{\mathrm{d}}=\frac{1}{R_{\mathrm{tot}}}=\frac{1}{R_{\mathrm{a}}}+\frac{1}{R_{\mathrm{b}}}+\frac{1}{R_{\mathrm{c}}}
$$

This indicates that factors related to plant interaction with atmospheric pollutants are as follows: aerodynamic resistance, $R_{\mathrm{a}}$ depends on meteorology, whereas boundary $\left(R_{\mathrm{b}}\right)$ and surface resistance $\left(R_{\mathrm{c}}\right)$ depend on the friction and shear of the leaf surface as well as the size of the pollutant particle [56].

Factors connected with plants Plant foliage acts as a sink for PM deposition. At least in part, it is attributed to electromagnetic charge of the leaf surface, connected with the plant taxa. A species' ability to immobilize air contaminants is regarded as the key factor connected with plants themselves. Among the most relevant traits of a plant species' ability to capture airborne pollutants are the leaf area index (LAI), morphology, anatomy (the complexity of the leaf surface and structure, the thickness of the wax layer, the presence of trichomes, etc.), and the stomatal density [53, 57-59]. These features are involved with the wettability and resistance of the leaf against being "occupied" by the pollutant particles. They are also responsible for the strength with which pollutant particles are attached to the leaf and not re-suspended in the air or washed by precipitation.

Leaf area index (LAI) LAI expresses the ratio of the leaf area to the area of the ground surface. Trees, with the largest LAI, are the most effective aerosol depositors
$[58,60]$. More expressed LAI can be found among trees with small (e.g. Betula pendula Roth) or complex (Fraxinus excelsior L.) leaves. Needles of coniferous species are particularly effective $[61,62]$. Due to their prominent LAI, highly effective pollutant capture is also observed in climbing species, like ivy Hedera helix L. [63]. Presently, climbers are often included into green infrastructure in cities as a solution for air purification, and urban heat island (UHI) mitigation.

Morphological characteristics of leaf surfaces Generally, the leaf trichomes are considered to improve the efficiency of air purification. Yet, the influence of trichomes is not unequivocal. In numerous observations, the correlation between the presence of trichomes and the amount of PM was not confirmed [57, 58, 64]. It seems to be related rather with the trichome morphology, density, arrangement and chemistry, than just their mere presence, so taking only this feature as a factor may be misleading. Going into details, in some species, like Alchemilla mollis (Buser) Rothm. or Triticum aestivum L., trichomes form a water-repellent layer [65, 66], whereas their structure in other species is favorable for particle capturing. Another feature which may favor PM capture is foliar roughness [67]. The ridges (at a scale of 1-2 $\mu \mathrm{m}$ ) on leaf surfaces were more efficient at accumulating PM, particularly $\mathrm{PM}_{2.5}$, compared with the roughness $(P-V$ distance) of $5-20-\mu \mathrm{m}$ scale [68]. Yet, similarly to trichomes, the effects of groove presence seems to be elusive [69]. Facing the complexity of leaf surface structures and how they relate to PM capture, it seems reasonable to rather research the comprehensive ability of different plant species for air purification. Such method was introduced by Sgrigna et al. [69]. They proposed Accumulation Index $A_{\mathrm{i}}$, considering the foliar roughness, trichome presence, stomatal density, and macromorphological traits of leaves: complexity of margins, leaf shape, leaf growth expansion, and the type of foliage (evergreen or deciduous). Save for surface complexity, anatomical structure of needles of coniferous species, specifically, the number and location of resin channels seems to be responsible for trapping xenobiotics [70].

Cuticle The presence of wax cuticles is considered to be a factor responsible for a plant's potential for air purification. Yet, there are many reports that contradict this statement. No statistical correlation between the presence of wax cuticles and air purification abilities was evidenced for 8 tree and 4 shrub species in Poland. Detailed studies indicated such relationship only for two species and a single PM category, i.e. for $\mathrm{PM}_{2.5}$ deposited in the wax layer of Forsythia $\times$ intermedia Zabel leaves and coarse particles on leaves of Tilia cordata Mill. [71]. Similarly, no such relationship was found for trees in Beijing [57]. Moreover, Eucalyptus globulus Labill., despite its 
well-developed cuticles, had the lowest ability to collect PM among species studied by Freer-Smith et al. [62]. This suggests that the efficiency of PM capture depends rather on the chemical structure of the cuticle and the lipophilic or polar character of the pollutant, than the amount of wax [71, 72]. For example, it may be related to the structure of wax crystals on cuticle surfaces, hydrophilicity of the amorphous waxes, as well as the length (from about 2 to $6 \mathrm{~nm}$ ) and chemical structure of wax chains, protruding from crystalline regions. High effectiveness of xenobiotic capture of conifer needles is, among others, attributed to the presence of long-chained polyesters [73]. Water permeability of the cuticles, attributed to the amount of polysaccharic strains, may be also involved in a plant's ability to retain polar compounds and ions. The highest performance of both features, which covers the same group of species, can support this suggestion. According to Riederer and Schreiber [74], the highest permeability of leaf cuticles is observed within deciduous trees in temperate climatic zones. Many of them, like Betula pendula, Tilia cordata, Syringa reticulata (Blume) H.Hara and Magnolia denudata Desr. are also the most efficient in PM capturing [75]. On the other hand, super-hydrophobic character of the mentioned Eucalyptus globulus cuticles seems to be the reason of the poor PM deposition. Liang et al. [57] found the relationship between the amount of captured PM and epicuticular wax ultrastructure. Because interfacial area affects the adhesion force, the most beneficial one was the thin wax film of elm Ulmus pumila L. in contrast to the dense tubular wax of Gingko biloba.

Phyllosphere Recent research draws attention on another aspect that can explain the positive correlation between the cuticle thickness and plant immobilization of ambient pollutants, which is the phyllosphere [76]. Leaves and other plant organs are colonized by bacteria, fungi, yeast, and algae. Much has been written regarding the ability of endophytic fungi and bacteria to degrade toxic contaminants, for example PAHs, which are then used as a source of carbon and energy [77, 78], but little is known about ones colonizing the surface of leaves. Wei et al. [79] list, among others, the following bacteria: Methylobacterium, Sphingomonas, Beijerinckia, Azotobacter, Klebsiella, and Stigonema, and fungi: Aureobasidium, Cladosporium, and Taphrina, yet their communities may differ according to the plant species, habitat conditions, or even the type of pollutants. Many of them are very efficient in capture and detoxification of air contaminants. Their population in five ornamental species growing on the roadsides of Sri Lanka ranged from $1.28 \times 10^{3}$ to $9.6 \times 10^{6} \mathrm{CFU} \mathrm{g}^{-1}$ (from total $6.2 \times 10^{5}$ to $8.1 \times 10^{8} \mathrm{CFU} \mathrm{g}^{-1}$ ), with the most densely populated phyllosphere of Ixora chinensis Lam.
Among them Aspergillus, Cladosporium, Nigrosporium, Trichoderma, Mucor, Penicillium, Pericornia, Humicola, Broomella, Coletritichum, Cylindrocarpon, Acremonium and Aeurobacidium. Penicillium oxalicum degrading $80 \%$ phenanthrenes and 96\% naphthalene, and Coletritichum siamense degrading xylene, phenanthrene, naphthalene, and toluene in a range of $52-68.9 \%$ occurred to be superior to others [80].

Bacteria are a more frequently studied microbes of the phyllosphere. As Yutthammo et al. [76] reported, the total phyllospheric bacteria of ten ornamental species in Bangkok accounted for $2.31 \times 10^{3}$ to $1.25 \times 10^{5} \mathrm{MPN}$ $\mathrm{g}^{-1}$, of which the amount of PAH detoxifying bacteria ranged from 1 to $10 \%$. Further studies allowed to classify the PAH degrading bacteria Wrightia religiosa (Teijsm. \& Binn.) Benth. ex Kurz phyllosphere: Sphingomonas, Acinetobacter, Mycobacterium, Pseudomonas, and many non-cultivable taxa from. They were effective in the detoxification of both low- and high-molecular-weight compounds. Apart from Pseudomonas, PAH-degrading species from different genera, including Microbacterium, Rhizobium, and Deinococcus were identified on Ixora chinensis leaves [81]. In Magnolia grandiflora L. and Cedrus deodara (Roxb. ex D.Don) G.Don phyllosphere Franzetti et al. [82] identified Hymenobacter, Sphingomonas, Methylobacterium and Massilia, but they were not able to distinguish the exact taxa responsible for the xenobiotic catalysis. The latest findings proved that not a single species, but whole microbial consortia may be responsible for PAH degradation [83], and this may be the reason for these difficulties. However, due to the negative interactions among different bacterial populations, their effectiveness may be limited [84], Yet, the interplay between the plant host and its microbiota seems to be of prominent meaning [85]. The interaction between the plant and the microorganisms is involved in many metabolic processes and include, among others, bio-fertilization, stimulation of growth and development (e.g. bacteria-derived IAA) as well as stress mitigation via antioxidative properties of some bacteria and fungi [86, 87]. Mitigation of plant stress supports stabilization of ambient pollutants, e.g. heavy metals [87], but from an ecological point of view their catabolic potential towards contaminants seems to be of major importance. A transcriptomic analysis confirmed that PAHs initiated the expression of genes encoding enzymes responsible for different stages of xenobiotic degradation [51]. For example, endophytic microbial degradation of PAHs takes place via the cytochrome P450-mediated pathway [88]. Research on whether similar relationships exist in the phyllosphere is in progress [87]. Until recently, the presence of PAH-catabolic enzymes, like naphthalene-1,2-dioxygenase, aryl-alcohol dehydrogenase, 
catechol-1,2-dioxygenase and catechol-2,3-dioxygenase was confirmed in phyllospheric bacteria [82]. In fungi, the monocyclic aromatic hydrocarbons (MAH) and PAH-degrading ability are often connected with lignindegrading systems and the presence of lignin peroxidase, manganese peroxidase, and laccase, which is also responsible for wood-decaying. According to Kannangara et al. [89] manganese peroxidase was the key enzyme in naphthalene degradation, while strains of non-lignolytic fungi took part in the degradation of PAH (benzene, toluene, and xylene). Their ability for this process is based on the activity of distinct enzymes, like cellulases and starchdegrading amylases. In contrast to bacteria, PAHs cannot be the only source of energy for fungi. What is more, most of them are not able to degrade high-molecularweight PAHs. Thus, for full degradation, the complex cooperation between microorganisms from different kingdoms is in some cases pivotal and include exchanging byproducts and metabolites. Moreover, fungal mycelia may act as transport network for bacteria, supporting their chemotropism towards PAHs [51].

Degradation is not the sole pathway of plant-microbiome interplay. Phyllosphere-derived enhancement of plant growth, by plant hormone production, increased nutrient availability (e.g. by production of organic acids), support stress tolerances leading to an increased LAI, therefore the area for PM accumulation [86]. Phyllospheric microorganisms also improve the bioavailability of pollutants by excretion of biosurfactants [51]. On the other hand, the interaction between plants and microorganisms involves positive feedback from plants, which can enhance the degradation abilities of microorganisms. It was observed that some plant products, like salicylic acid, flavonoids, and fatty acids can stimulate the expression of bacterial genes responsible for xenobiotic degradation $[51,88,90]$.

Factors connected with the environment and city design The influence of environmental factors on plantderived air purification harbors diversified features: from the traits connected with PM itself, air circulation, to the relative humidity and temperature [91]. For PM, important features include its concentration, size, and chemical character. The concentration drops down along with the distance from the source of contaminants [92], hence the most beneficial are plants growing close to the site of the PM origin. For the greatest effectiveness, a plant barrier should be placed between the source of pollutants and the exposed people, taking into account the usual wind directions [92]. According to Morakinyo et al. [93], a noticeable drop in PM levels is observed in a certain distance from the barrier, 7-12 $\mathrm{m}$ for oblique winds and 8-18 $\mathrm{m}$ for perpendicular winds. To achieve dense deposition, it is crucial to create conditions for air circulation through the canopy. The air movement is one of the key factors in PM deposition as it drives particles close to the leaves. A positive correlation between pollutant deposition and wind speed was revealed [94, 95]. Wind acceleration from 3 to $9 \mathrm{~m} \mathrm{~s}^{-1}$ resulted in a significant rise in the deposition velocity and capture efficiency for all examined taxa of trees [61]. Yet, the wind speed, direction, and the rate of foliage penetration may be modified by various factors, including the climate and weather, the height and design of architectural barriers and plants themselves. Threedimensional geometry of a city is associated with numerous canyons between buildings, noise barriers, and others which act as sinks for turbulence, limiting the contaminant dispersion and leading to the local rise in pollution [96]. For this reason, the proper design of city infrastructure is required. What is more, tall and dense trees forming barriers that are passed above, rather than penetrated, are not desirable $[59,97]$. Instead, planting lower trees with loose branches and foliage, and including hedges or other types of lower vegetation beneath the trees is suggested [96]. In open spaces, planting "green spots" with numerous trees and diversified vegetation, spatially separated from the source of pollution, is recommended.

The other aspect of PM capture is the retention of airborne particles. Many airborne pollutants are stored on leaves temporarily. Due to winds, PM is re-suspended in the atmosphere and with rain, it is washed off onto the soil. Greater amounts of airborne pollutants deposited by deciduous species get to the soil with the falling of leaves. Regarding the effects of rainfall on PM removal, $\mathrm{Xu}$ et al. [98] indicated the key role of precipitation intensity through increased kinetic energy of drops. It is applied within the intensity not exceeding $30 \mathrm{~mm} \mathrm{~h}^{-1}$. A rise above this value does not substantially increase PM removal $[98,99]$. The influence of the duration was much weaker, as PM removal was the strongest at the beginning of a rainfall, i.e. first $2.5 \mathrm{~mm}$ of precipitation (up to $30 \mu \mathrm{g} \mathrm{cm}^{-1}$ ) $[98,99]$. The amount of re-suspended particles depends also on the leaf surface complexity and wettability. Wash-off experiments indicated that the rates of PM removal from leaves can differ strongly within the range: from $6.4 \%$ of total PM for Platanus $\times$ hispanica to $87.6 \%$ for Olea europea L. [100]. Generally, coarse particles are washed off at higher rates as they are usually deposited on the leaf surface, whereas fine particles are more likely embedded in the wax layer. To move them from the cuticles, a heavy rain event is required [99]. Similarly, leaf surface adhesiveness, roughness, and more importantly, the stomatal density are connected with the rate of resuspension caused by winds [101]. The other factor controlling the release of PM is wind speed. The amount of released PM increases with 
wind acceleration, when aerodynamic, vibrational, and mechanical removal forces break the forces of adhesion, i.e. van der Waals, capillary, and electrostatic [101, 102]. These forces are modified by the relative humidity. A high humidity enhances the adhesion due to capillary condensation between the PM and a surface [102]. Regardless of the weather conditions, deciduous species lose deposited pollutants every year in autumn, while contaminant retention of coniferous trees lasts $2-5$ years, depending on the longevity of needles of a species.

\section{The role of green infrastructure in PM reduction}

A substantial increase in green coverage and species diversity can be implied by green and blue infrastructure solutions, like green roofs, green walls, and vegetated water retaining systems, as well as urban farming [18, 103, 104]. The significance of green infrastructure in cities is underlined in the newest reports released worldwide: the 2030 EU Biodiversity Strategy [18], and UN Habitat [105] serve as a means of providing/supporting sustainable and inclusive development of urban areas.

\section{Green roofs}

Green roofs are at present one of the most popular and widespread green technologies, supported by numerous policies or demanded by law worldwide. Their pivotal function in the city is water retention, but their role in climate improvement (mitigation of UHI, $\mathrm{CO}_{2}$ sequestration, air pollution removal, and energy savings in buildings) is also appreciated. The key factor influencing their biodiversity and ecological services is the thickness of the substrate layer. The deeper it is, the richer selection of plants can be applied. In extensive roofs, with the thinnest substrate of 2-20 cm [106], usually succulent species such as Sedum sp. can thrive. However, they are regarded as non-coherent pollutant removers. For example, the potential of Sedum album L. in trapping PM was $0.42 \mathrm{~g} \mathrm{~m}^{-2}$ year $^{-1}$, compared to 3.21 and $1.81 \mathrm{~g} \mathrm{~m}^{-2}$ year $^{-1}$ of Festuca rubra L. and Agrostis stolonifera L., respectively. Yet, in semiarid areas, this species exhibited a higher rate of PM deposition reaching $29.32 \mu \mathrm{g} \mathrm{cm}^{-2} \mathrm{~h}^{-1}$, compared to other Sedum species (with S. reflexum L., and S. palmeri S.Watson having the lowest effectiveness) and plants, such as Pittosporum tobira (Thunb.) W.T.Aiton and Erigeron karvinskianus (DC.) Kuntze (1.38 and $1.62 \mu \mathrm{g} \mathrm{cm}^{-2} \mathrm{~h}^{-1}$ respectively) [107]. Due to potentially more abundant and diversified vegetation, intensive and semi-intensive green roofs are more effective in green roof PM deposition. In a study conducted in Montreal, the GRs covered with Pinus mugo var. pumilio (Haenke) Zenari on the buildings heated with wood were able to remove $4.00 \mathrm{~g} \mathrm{~m}^{-2}$ of $\mathrm{PM}_{10}$ and $1.52 \mathrm{~g} \mathrm{~m}^{-2}$ of $\mathrm{PM}_{2.5}$ annually [108]. The ability of green roofs to capture PM is often compared to that of trees. It can be noticed that green roofs are not as efficient as trees, although, in some cases, their PM capture ability can reach values close to those achieved by trees [109]. Yet, it is worth underlining that green roofs are not competitors to trees, but act as their supplement [110]. Their popularity and area that they occupy in cities add substantial improvement to air pollution reduction. For example, according to data from 2015 there were 4 million $\mathrm{m}^{2}$ of green roofs in Berlin, 3.148 million $\mathrm{m}^{2}$ in Munich and 1.345 million $\mathrm{m}^{2}$ in Tokyo. The greatest green roof area per capita belonged to Basel, Switzerland, a town with a population of 175,000 and 1 million $\mathrm{m}^{2}$ of green roofs $\left(5.71 \mathrm{~m}^{2}\right.$ per inhabitant). These data have changed noticeably as green roofs have continuously been adopted [111].

\section{Living walls}

Similarly, green walls are facing a growing interest for mitigating air pollution. Depending on the species composition, the LAI of green walls is around $1-2 \mathrm{~m}^{2}$ for every $\mathrm{m}^{2}$ of wall. In the study of Weerakkody et al. from Stoke-a-Trent (UK), multi-species green walls abated, on average, $122.08 \times 10^{7} \quad \mathrm{PM}_{1}, 8.24 \times 10^{7} \quad \mathrm{PM}_{2.5}$ and $4.45 \times 10^{7} \mathrm{PM}_{10}$ [112]. However, to acquire a significant purifying effect, their localization should be welldesigned [59]. The most pronounced influence can be observed when green walls are installed in small, closed spaces, such as street canyons. Wind speed and canyon geometry determine the PM concentration in street canyons. At the most favorable aspect ratio of height/ weight $(h / w)=2$ and low $\left(0.5 \mathrm{~m} \mathrm{~s}^{-1}\right)$ wind speed, green walls may enhance the sink for pollutants and contribute to the drop of $\mathrm{PM}_{10}$ concentration in street canyons by $60 \%$ [94]. It may also positively affect the $\mathrm{PM}_{2.5}$ concentration behind the wall at the pedestrian height $(1.4 \mathrm{~m})$, but increase it over the wall [93]. The distance of worsened air quality rises with increasing heights of green walls. Facing such an occurrence, it is not recommended to install green walls close to high buildings. Following these phenomena, modeling studies of particular cases should be conducted, taking into consideration numerous factors such as plant species, canopy volume, wind speed, and direction, as well as the urban geometry [93, 94].

Recently, a great progress has been done with green walls towards their utilization in PM capture. To increase the purifying potential of plants air flow through canopy and growing medium with plant rhizosphere is supported by active mechanical ventilation. Generally, active green wall technology, called also botanical filtration, is known for its efficiency in VOCs and PM abatement indoors [113-115], however it is worth noticing, that 
considerable amount of PM indoors is of outdoor origin [116]. According to Irga et al. [117], the single-pass removal efficiency (SPRE) of ambient indoor VOCs, which can reach $70 \%$ and does not depend on plant species, whereas species of plant determines single VOC removal. Chlorophytum orchidastrum Lindl. and Schefflera arboricola (Hayata) Merr. were the most efficient in ethyl acetate removal, whereas Nematanthus glabra in benzene. Chlorophytum orchidastrum also occurred to be an effective purifier of PM, yet the most PM of all fractions was captured by Nephrolepis exaltata bostoniensis (e.g. SPRE for $\mathrm{PM}_{5-10}$ reached 92.46\%) [118]. Recent studies dealt also with application of active green walls for ambient PM removal as well [119]. The results confirmed some reduction of PM after Black Summer in Sydney in 2020 and suggest further research on the use of botanical filtration outdoors.

Except for numerous reports about the use of botanical filtration indoors, there is still too little knowledge about them. None of the studies, to our best knowledge, compares effectiveness of pollution abatement of passive and active green walls [120]. The mechanism which is mainly involved in air purification is also unclear, although in some papers rhizosphere activity is considered to be more effective in PM and VOCs removal [19, 120-122]. Increased area of capturing surface, abundant microflora connected with plant taxa and growing medium and root exudates are involved in rhizosphere predominance [117, 123]. Hence, the preservation of microbial activity is one of the main concerns for air pollution abatement. It may be sustained by plant species and medium selection, or continuous inoculation with new bacteria or fungi, e.g. with irrigation [120]. Another consideration should be given to growing media. They should maintain both, plant growth and microbial abundance and diversity. Very often growing media themselves can reduce air contaminants. Porous materials with increased surface, like activated carbon, zeolite, silica gel and polymers are the most beneficial for pollution capture $[124,125]$.

\section{Water reservoirs}

Wind speed seems to play a crucial role in PM removal by wetlands. Rivers and water reservoirs, as parts of blue infrastructure, seem to be undervalued in terms of their pollutant removal capacity. Apart from dry deposition on the surface of water [126] wetland plant species are involved in PM deposition. Due to a lower LAI, their rates of purifying the air are lower than those in a forest, yet the deposition velocities may be almost the same in these two types of vegetation. This indicates the high potential of wetland plants, such as Phragmites australis (Cav.) Trin. ex Steud., Scirpus Validus Vahl, and Iris spp. for both fine and coarse particle removal [127].
Another study indicated the high PM capture efficiency of Phragmites australis (42.14 $1.30 \mu \mathrm{g} \mathrm{cm}^{-2}$ of $\mathrm{PM}_{10}$ and $11.30 \mu \mathrm{g} \mathrm{cm}^{-2}$ of $\mathrm{PM}_{2.5}$ ). These rates were respectively more than 30 and 3 times higher than the lowest such efficiency observed in Lythrum salicaria L. (4.58 and $1.30 \mu \mathrm{g} \mathrm{cm}^{-2}$, respectively) [128]. Yan et al. [99] demonstrated an even higher potential of Typha orientalis C.Presl for PM capture.

\section{Urban farming}

Another trend in green infrastructure is urban horticulture and agriculture. It is a response to the growing demand of fresh and local foods in order to shorten the food chain. It is perfectly included into the idea of a circular city, where waste organic matter and wastewater is reused. It involves a number of advanced sustainable green technologies, such as hydro- and aeroponics, vertical farming, rooftop gardens, as well as traditional forms of growing food like private kitchen gardens and allotments. A new, but more and more popular form of food production are community gardens which aim at integrating local societies.

To supply food, urban food production must solve the problem of environmental pollution. PM suspended in the air is exceptionally hazardous as they contain harmful heavy metals and PAHs. They can enter plants directly from the air or indirectly from the soil, after its deposition on soil surface.

Metals do not undergo decomposition so they accumulate in soils at high levels $[129,130]$. From soils, they enter plants via the roots and accumulate in plant tissues. The other pathway, through leaves and stems, is less common. Their risk to human health comes from ingesting contaminated food and, to a lesser extent, inhalation of metals suspended in the air and contacting these metals through the skin [131]. In the human body, they cause multiple injuries to the liver, kidneys, brain, bones, lungs, and impair fertility, depending on the element. Some of them (As, $\mathrm{Cd}, \mathrm{Cr}, \mathrm{Ni}, \mathrm{Pb}, \mathrm{Zn}$, and $\mathrm{V}$ ) are also responsible for various types of cancer [132, 133]. According to Romanian studies, these toxic effects may contribute to decrease in the human life expectancy by 9-10 years [134]. An important issue is also processed food made of polluted crops, in which metal contamination can condense.

Heavy metal load on leaves takes place via the same mechanisms as other PM: by being captured on the leaf surface and encapsulated in the cuticle. Metals trapped on leaf surfaces may be removed in great part by washing [135], so the main risk from metals comes mostly from penetration of leaves in two ways [117, 123]: hydrophilic compounds get to leaf tissue through the stomata or pores in the cuticle wax layer, like cracks, ectodesmata, 
and aqueous pores, while lipophilic ones penetrate the cuticle. This phenomenon highly depends on the metal speciation. For example, $\mathrm{Pb}$ in $\mathrm{PM}$ can exist in the form of $\mathrm{PbS}, \mathrm{PbSO}_{4}, \mathrm{PbSO}_{4}-\mathrm{PbO}$, a-PbO, and $\mathrm{PbO}[136,137]$. Furthermore, heavy metals themselves can interact with the cuticle and change its structure and decrease its permeability [138]. The trapped metal/metalloids are also exposed to humidity, high temperature, solar radiation, and microbiological activity of the phyllosphere which can change their accessibility. Yet not all the processes connected with metals entering plants through leaves are revealed in contrast to soil-derived pollution. In terms of transport, it is suspected that air-derived metals and metalloids are more reluctant to move than those coming from the soil. It may by caused by the fact, corroborated for $\mathrm{Pb}, \mathrm{Cu}, \mathrm{Zn}$ and $\mathrm{Mn}$, that they express a high binding capacity to cellulose and are immobilized in the cell walls of the leaf tissue [138]. On the other hand, there are metals with a high mobility in plants. Research of Natasha et al. [139] indicated that arsenic, after foliar application, was transported to the roots, contrary to lead, which was only accumulated in the leaves.

The potential of a plant species to accumulate metal or metalloids seems to be of the greatest importance in airborne pollution ingestion via vegetables $[119,126]$, yet there exists little research to classify crop species as tolerant or hyperaccumulators towards a specific pollutant [138]. As ingesting is the main pathway of entering the human body, the quality of edible parts of crop plants is of the greatest concern. Due to PM capture and high immobilization of metal and metalloids, leafy vegetables are the least secure for cultivation in urban areas [139, 140] (Table 1). Previous experiments give evidence that lettuce Lactuca sativa $\mathrm{L}$. collects alleviated amounts of $\mathrm{Al}, \mathrm{As}, \mathrm{Mn}, \mathrm{Pb}$ and $\mathrm{Cu}$, Spinacia oleracea $\mathrm{L}$.-As, Cd, $\mathrm{Zn}$ and Fe [124, 127], Brassica oleracea L.-Zn and Sb [132], while Chrysanthemum coronarium L.-Cr [141]. Generally, the health risk assessment which includes numerous parameters such as the hazard index (HI) for adult and children, hazard quotient (HQ), estimated daily intake (EDI), maximum daily intake (MDI), lifetime cancer risk (ILTCR), and total hazard quotient (THQ). This methodology allows assessments of the risk of a plant species and a metal pollutant, and indicates, for example, that hazard index of $\mathrm{Cd}, \mathrm{Zn}, \mathrm{Sb}$ in case of Brassica oleracea (0.924 for adults and 1.801 for children) is almost 20 times higher than that for Spinacia oleracea (0.053 and 0.103, respectively) [142]. The limit value of $\mathrm{HI}$ is 1.0 , which is exceeded in the case of $B$. oleracea for children.

Considering the toxicity and potential vulnerability of organisms, $\mathrm{As}, \mathrm{Cd}, \mathrm{Cr}, \mathrm{Pb}$, and $\mathrm{Hg}$ are believed to be the most hazardous [138]. Yet, numerous studies from Europe and the USA show that growing vegetables and fruits in cities can be safe, unless the cultures are in the vicinity of mines, heavy-traffic roads, and industrial companies as well as arable land being fertilized, at present or in the past, with sewage water or sludge. A study conducted by Noh et al. [141] suggest that washing of contaminated vegetables also helps to keep the level of PM below the limit value.

There are many routes via which PAHs can enter the human body, but ingestion is the most common and the most profound [50]. Contrary to heavy metals, intake of PAHs from fruits and vegetables is estimated to be $5-10 \%$, while their global consumption is around $30 \%$ of all food products. The rest comes mainly from animal and oil products, much of them during food preparation and storage. Some PAHs can be produced by plants [143, 144]. Due to the high risk to PAHs present to the human and animal health, especially their carcinogenicity and mutagenicity, their presence in horticultural products draws attention in cultivation in polluted environments.

The biggest source of PAHs is the incomplete combustion of fossil and organic fuels. In a city, we can find numerous such sources: high traffic, industry, and stoves in residential areas [104]. For that reason, cultivation of vegetable and fruit crops in urban environments results in a higher PAH absorbance compared to that in rural areas $[50,145]$. As the above-ground parts of vegetables are polluted more than the underground parts, aerial exposition seems to be the main route of PAHs in urban crops [146]. Contrary to soil contamination, out of 16 PAHs which are usually analyzed, low-weight PAHs are usually accumulated on leaves. It is connected with their volatile and hydrophilic character [37].

The accumulation of PAHs in horticultural crops depends on the species, and even on the variety [50]. As in the case of HMs, leafy vegetables like lettuce and Chinese cabbage retain the greatest amount of PAHs [130, 132], yet, according to Jia et al. [147], the highest amount of $\sum$ PAHs was detected in romaine lettuce Lactuca sativa var. longifolia. The least hazardous vegetable for consumption seems to be cabbage [130, 132, 133]. In fruits, root vegetables, and fruiting vegetables the majority of accumulated PAHs is immobilized in peels, so it is possible to diminish the amount of ingested PAHs by removing the peels [148].

\section{The effects of urban vegetation on PM reduction}

The reduction of PM levels in the air was corroborated in numerous papers, indicating a negative correlation between the total green area and PM concentrations [91, 149-151]. Yet, most of them focuses on the role of trees in this phenomenon, although herbaceous plants substantially support the capture potential of trees [152]. McPherson et al. [153] estimates the amount of $\mathrm{PM}_{10}$ 
Table 1 The concentration of heavy metals ( $\mathrm{mg} \mathrm{kg}^{-1}$ of dry weight) on edible organs vegetables grown in different world cities

\begin{tabular}{|c|c|c|c|c|c|c|c|c|c|}
\hline Edible organ & Species & Country & References & $\mathrm{Pb}$ & $\mathrm{Cd}$ & $\mathrm{Cu}$ & $\mathrm{Ni}$ & $\mathrm{Cr}$ & $\mathrm{Zn}$ \\
\hline \multirow[t]{14}{*}{ Leaf } & $\begin{array}{l}\text { Lettuce } \\
\text { Lactuca sativa L. }\end{array}$ & France & [136] & 355.0 & & & & & \\
\hline & & France & [206] & 122.0 & 1.7 & 6.8 & & & 29.1 \\
\hline & & South Korea & [141] & $0.70-1.26$ & $0-0.08$ & & $6.54-8.36$ & $0.36-0.40$ & $49.6-62.2$ \\
\hline & & Romania & [134] & $68.3-118$ & $4.9-6.7$ & & $11.8-13.8$ & & $121.0-301.0$ \\
\hline & & Benin & [207] & $77.1-77.8$ & 0.3 & $3.8-7.9$ & & & $56.4-107.8$ \\
\hline & & Ecuador & [208] & $0-1.18$ & $0-0.56$ & & & & \\
\hline & $\begin{array}{l}\text { White cabbage } \\
\text { Brassica oleracea subsp. capitata (L.) } \\
\text { Metzg }\end{array}$ & Germany & [209] & 2.6 & 0.41 & 6.6 & 1.0 & 0.81 & 46.5 \\
\hline & & Benin & [207] & $52.6-78.9$ & $0-0.1$ & $1.8-3.9$ & - & - & $44.1-85.4$ \\
\hline & & China & {$[210]$} & $1.71^{\mathrm{a}}$ & $0.13^{\mathrm{a}}$ & $1.40^{\mathrm{a}}$ & - & - & $5.95^{\mathrm{a}}$ \\
\hline & $\begin{array}{l}\text { Chinese cabbage } \\
\text { Brassica rapa var. pekinensis (Lour.) } \\
\text { Hanelt }\end{array}$ & China & [210] & $1.17^{\mathrm{a}}$ & $0.34^{\mathrm{a}}$ & $1.69^{\mathrm{a}}$ & - & - & $12.4^{\mathrm{a}}$ \\
\hline & $\begin{array}{l}\text { Pakchoi } \\
\text { Brassica rapa var. chinensis (L.) Kitam }\end{array}$ & China & [210] & $2.79^{\mathrm{a}}$ & $1.2^{\mathrm{a}}$ & $3.07^{\mathrm{a}}$ & - & - & $14.3^{\mathrm{a}}$ \\
\hline & $\begin{array}{l}\text { Leek } \\
\text { Allium ampeloprasum L. }\end{array}$ & China & [210] & $4.03^{\mathrm{a}}$ & $0.39^{\mathrm{a}}$ & $2.17^{\mathrm{a}}$ & - & - & $8.63^{\mathrm{a}}$ \\
\hline & $\begin{array}{l}\text { Persley } \\
\text { Petroselinum crispum (Mill.) Fuss }\end{array}$ & France & [206] & 298.7 & 0.8 & 4.4 & - & - & 25.4 \\
\hline & $\begin{array}{l}\text { Spinach } \\
\text { Spinacia oleracea L. }\end{array}$ & South Korea & [141] & $0.59-1.16$ & 0 & & $7.17-50.9$ & $0.11-0.36$ & $91.53-122.1$ \\
\hline \multirow[t]{5}{*}{ Fruit } & $\begin{array}{l}\text { Tomato } \\
\text { Lycopersicon esculentum Mill }\end{array}$ & Germany & [209] & $0.1-6.7$ & $0.01-0.79$ & $3.5-16.0$ & $0.03-0.70$ & $0.11-0.63$ & $15.8-84.7$ \\
\hline & & Ecuador & [208] & $0-2.33$ & $0-0.66$ & & & & \\
\hline & & China & {$[210]$} & $0.72^{\mathrm{a}}$ & $0.39^{a}$ & $1.39^{\mathrm{a}}$ & & & $3.48^{\mathrm{a}}$ \\
\hline & $\begin{array}{l}\text { Pepper } \\
\text { Capsicum annuum L. }\end{array}$ & China & [210] & $1.94^{\mathrm{a}}$ & $0.23^{\mathrm{a}}$ & $2.0^{\mathrm{a}}$ & & & 4.3 \\
\hline & $\begin{array}{l}\text { Green beans } \\
\text { Phaseolus vulgaris L. }\end{array}$ & Germany & [209] & $0.1-3.5$ & $0-0.04$ & $3.5-10.5$ & $0.27-1.3$ & $0.08-0.46$ & $32.4-44.2$ \\
\hline \multirow[t]{4}{*}{ Root } & $\begin{array}{l}\text { Carrot } \\
\text { Daucus carota L. }\end{array}$ & Germany & [209] & $1.3-28.5$ & $5.4-23.2$ & $5.4-23.2$ & $0.07-0.47$ & $0.1-2.39$ & $23.3-122.8$ \\
\hline & & Belgium & [211] & $0.9-9.2^{a}$ & $5.6-10.9^{a}$ & & & & \\
\hline & $\begin{array}{l}\text { Celery } \\
\text { Apium graveolens } \\
\text { var. Rapaceum (Mill.) Poir }\end{array}$ & Belgium & [211] & $1.6-21.0^{\mathrm{a}}$ & & $\begin{array}{l}10.9- \\
40.1^{\mathrm{a}}\end{array}$ & & & \\
\hline & $\begin{array}{l}\text { Radish } \\
\text { Raphanus sativus } \mathrm{L} \text {. }\end{array}$ & China & [210] & $1.01^{\mathrm{a}}$ & $0.22^{\mathrm{a}}$ & $0.96^{\mathrm{a}}$ & & & $3.57^{\mathrm{a}}$ \\
\hline Stem & $\begin{array}{l}\text { Kohlrabi } \\
\text { Brassica oleracea } \\
\text { var. gongylodes } \mathrm{L} \text {. }\end{array}$ & Germany & [209] & $0.1-3.1$ & $0.03-0.15$ & $3.2-11.6$ & $0-0.91$ & $0.07-0.54$ & $20.6-50.3$ \\
\hline
\end{tabular}

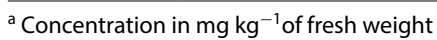

accumulated in trees in Chicago (USA) to be $212 \mathrm{t}$ per year. According to Nowak et al. [154] in the whole USA, this value for all airborne particles can reach 711,000 $\mathrm{t}$ year $^{-1}$. This means about $0.2-1.0 \%$ reduction in the PM levels. In Manchester (UK) city center, trees can store $0.24 \mathrm{t}$ of $\mathrm{PM}_{10}$ a year i.e. about $2.3 \%$ of $\mathrm{PM}_{10}$ in the area [107]. 850-2100 t of $\mathrm{PM}_{10}$ is removed yearly in London [155], an equivalent of $0.7-1.4 \%$. A high reduction in $\mathrm{PM}_{10}$ was also noted in Santiago de Chile [156]. In areas with high pollution and $26 \%$ vegetation cover, usually inhabited by low-income citizens, 1.6\% PM level reduction was achieved with trees and an additional 1.1\% with shrubs. Simulations give more promising results: data from London suggest that the maximum green coverage rate (56\% of the area) can locally adsorb $26 \%$ of suspended $\mathrm{PM}_{10}$, which would amount to $200 \mathrm{t}$ per year [157]. 
There are conditions that limit PM capture. Some are related to the city design, i.e. street canyons with dense tree canopies [40, 94]. Furthermore, in northern regions, vegetation seems to have a limited effect on PM capture [158].

\section{Methods of increasing the PM capture potential of plants Species selection according to their PM capture potential}

The differences in PM accumulation capacity among tree species can be 10 to 20 -fold [159], thus thorough an appropriate choice of species, a considerable improvement of air purification may be achieved. In Tehran (Iran), the effect of replacing trees with species with a higher potential for xenobiotic capture can be estimated for $14.4 \%\left(\mathrm{CO}, \mathrm{NO}_{2}, \mathrm{O}_{3}, \mathrm{SO}_{2}\right.$ and $\left.\mathrm{PM}_{2.5}\right)$, while the improvement in air the $\mathrm{PM}_{2.5}$ level is valued for $10.69 \%$ [160]. Moreover, a 40\% improvement can be afforded by planting additional 150,000 trees with a high PM capture potential.

Many studies have analyzed the PM capture potential of trees, especially species originating from temperate climates from Europe, Asia, and North America [161]. In terms of PM capture, the most frequently analyzed tree taxa include Acer, Fraxinus, Pinus, Prunus, Populus, Quercus, Ulmus, Tilia, Platanus and Betula genera. Yet, the differences in the experimental design and conditions with the dominating role of climate and seasons make the comparison of results very difficult. Another problem is the variety of values taken into account: foliar retention Cp (usually expressed in $\mu \mathrm{g} \mathrm{cm}^{-2}$ ) (Table 2) [71, 162], deposition velocities $\left(\mathrm{cm} \mathrm{s}^{-1}\right)[62,163]$, but also daily/ yearly retention efficiency $\left(\mathrm{mg} \mathrm{m}^{-2} \mathrm{~d}^{-1}\right)[164,165]$, number density (particles $\mathrm{mm}^{-2}$ ) [53, 166], and saturation isothermal remanent magnetization (SIRM) $(\mu \mathrm{A})$ [167]. Furthermore, results of PM abatement may differ according to the analytical method used. For instance, in the study by Sgrigna et al. [69] the capture depositions analyzed by vacuum filtration and energy-dispersive X-ray spectroscopy methods were consistent only for six tree species out of twelve. Distinct results, among others, were achieved in the case of Platanus acerifolia. It expressed a high PM capture efficiency by SEM/EDX, but a low PM capture efficiency when analyzed by F/V method. After the use of the same method Dzierzanowski et al. [71] also qualified $P$. acerifolia as a lowly effective purifier, whereas in other publications it was also mentioned among trees with the highest potential for PM capture $[166,168]$. Such discrepancies were revealed for other species, like Tilia cordata [71, 162] and Styphnolobium japonicum (L.) Schott $[68,169,170]$. According to Sgrigna et al. [69], this phenomenon may result from the lack of specific solvents to extract all the particles from the different cuticle layers. Contrary to this, consistent results exist in the case of species with a low PM capture potential, such as Ginkgo biloba, Ligustrum lucidum W.T.Aiton, Ailanthus altissima (Mill.) Swingle and Eucalyptus sp. [149, 151, 171, 172]. Deposition data are supported by deposition velocities, with the lowest value for Eucalyptus globulus-0.04 $\mathrm{cm} \mathrm{s}^{-1}, 0.19 \mathrm{~cm} \mathrm{~s}^{-1}$ for Acer campestre L. and A. pseudoplatanus L., $0.42 \mathrm{~cm} \mathrm{~s}^{-1} F$. excelsior and the highest for Pinus nigra J.F.Arnold-6.84 $\mathrm{cm} \mathrm{s}^{-1}$ [173].

Although numerous studies confirm PM abatement by herbaceous plants indoors [113, 118, 174], limited studies have been involved in the purification potential of herbaceous species in cities. Available records give evidence that these plants are less potent purifiers, but their ubiquitous appearance can substantially contribute to PM reduction. Out of twenty species growing in vertical gardens in the UK, non-woody plants accumulated less particles than shrubs did [112]. The best herbaceous accumulators occurred to be Thymus vulgaris L. and Carex caryophyllea Lat. Their leaf features that bear resemblance to those of trees seem to govern their ability to immobilize PM, yet the plant architecture also partakes in it-plants with tall and leafy shoots are considered to be the best purifiers [152]. Among European synanthropic plants, Polygonum aviculare L. and Sysimbrium loeselii (L.) Rich. are the most potent in PM retention, whereas Festuca rubra is the least effective [152] (Table 3). Another type of herbaceous vegetation is grasslands. Grasslands, including recreational and representative areas with mown lawn, but also rough grasslands occupy a huge percentage of city areas. In Sweden it accounted for $15-32 \%$ of the urban area [175]. In China approximately 40,000 ha of lawn are established every year [176]. Due to such a broad cover, grasses substantially partake in the PM abatement, even if they collect about 30\% of PM kept by the forest [177]. Cowherd et al. [178] gave evidence for the distinct potential of low, intensively mown lawn, which abated less than $10 \%$ of $\mathrm{PM}_{10}$ and tall grasses which retained about 35-45\%, compared to $45-67 \%$ of $\mathrm{PM}_{10}$ retained by cedar forests. Modern trends of increasing biodiversity of urban grasslands and decreasing costs of lawn maintenance by seldomly mowing [179] may contribute to a substantial air quality improvement.

Apart from total deposition, each of the species expresses different potential to various aerosols. It seems reasonable to adjust vegetation to the local PM composition. For example, Quercus ilex L., which is regarded a weak purifier, can be used more effectively for $\mathrm{Pb}$ capture than $P$. acerifolia and T. cordata [100], which are otherwise considered efficient PM depositors. Sorbus aucuparia L. occurred to be efficient in polychlorinated biphenyls accumulation [180]. According to Fellet et al. [181] Viburnum lucidum Mill. occurred to be a weak 


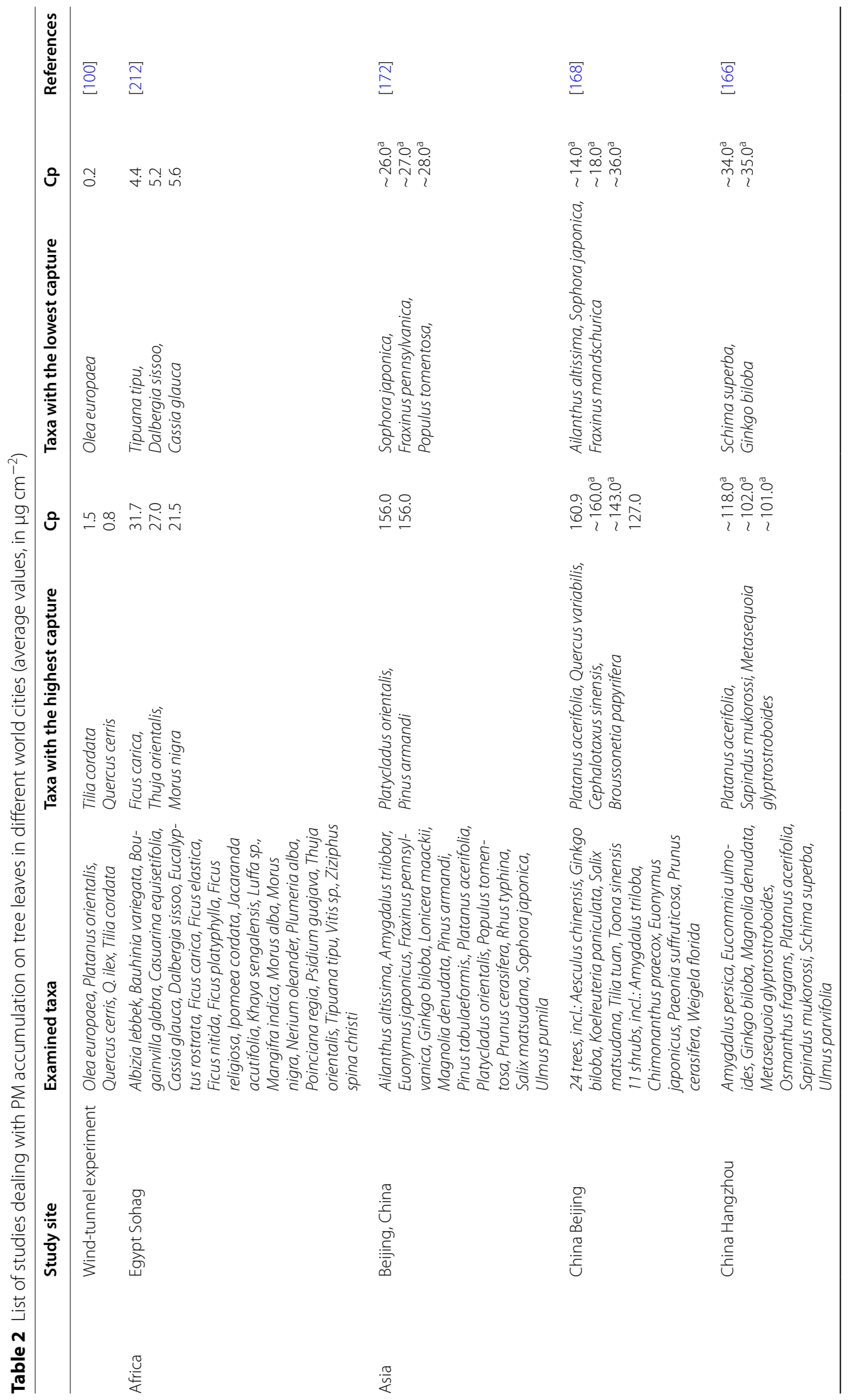




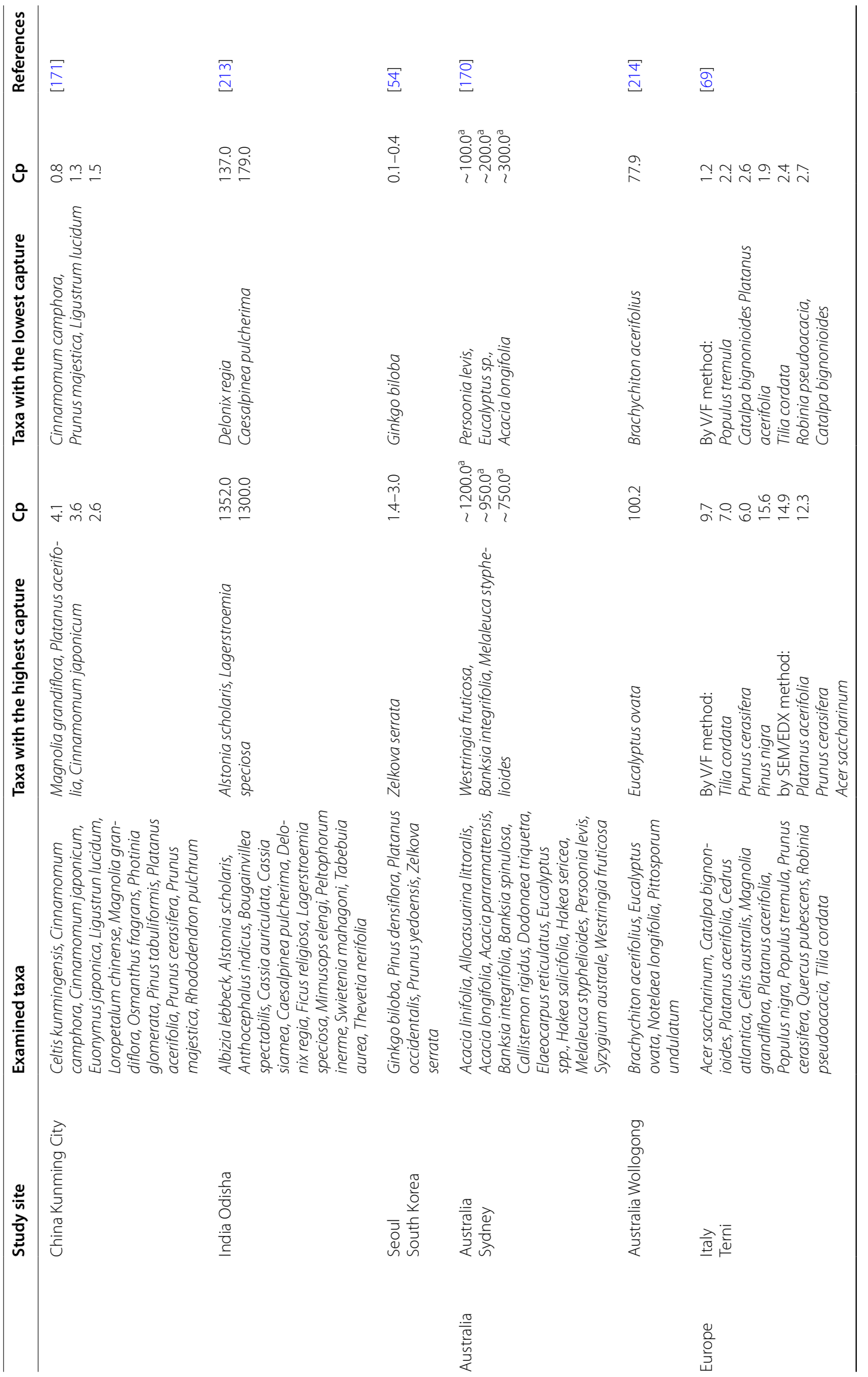




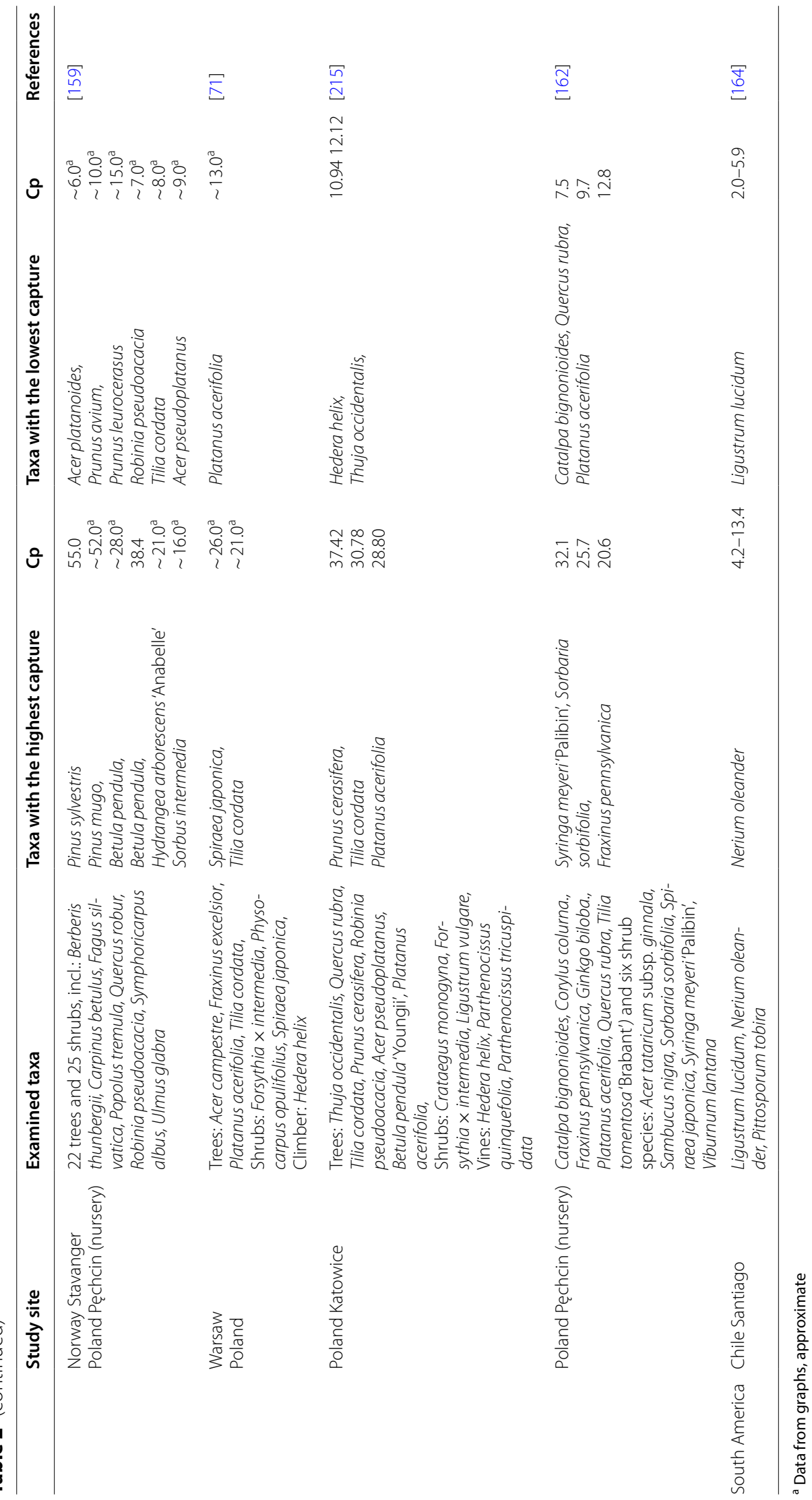


collector of $\Sigma \mathrm{PAHs}$, but it accumulated the greatest amounts of anthracene.

As biogenic emissions are about 9 times greater than anthropogenic ones, the potential of trees to emit BVOCs should be taken into consideration. The major part, i.e. $35-40 \%$ of SOA formation belongs to monoterpenes, $15-32 \%$ to isoprene and $10 \%$ to sesquiterpenes [26]. For this reason, many papers suggest planting low-BVOCemitting trees in urban environments [182, 183]. Fitzky et al. [184] characterizes tree species according to their potential emission rates (Table 4):

Among species cultivated in Europe, the authors mention Quercus robur L., Q. pubescens Willd., Populus nigra L. and P. tremula L. as high isoprene emitters, as well as Fagus silvatica L. as a high monoterpene emitter. On the other hand, Acer platanoides L., Ulmus minor Mill., Fraxinus excelsior L., and Tilia platyphyllos Scop. are considered low BVOC emitters. The genus Quercus was also responsible for high emissions of isoprene in Japan, whereas Cryptomeria japonica was the greatest producer of mono- and sesquirterpenes [182]. Low emitters of BVOC among tropical trees in Santiago de Chile were Schinus mole L., Quillaja saponaria Poir. and Quercus suber L. [185]. In studies conducted in India, Ceiba petendra L., Cinnamomum zeylanicum Bereyn., Azadirachta indica A.Juss., Melia azedarach L., Chukrasia tabularis A.Juss., Terminalia arauna Roxb. and T. bellirica Roxb. expressed low isoprene emission rates, whereas Dalbergia sissoo Linn., Ficus religiosa L. and F. infectoria Willd, emitted high levels of isoprene [186].

\section{Increased biodiversity}

Loss of biodiversity is one of the major threats to the environment in the contemporary world. Besides the green coverage rate, this phenomenon is assigned to have a fundamental importance in PM reduction. The poor species composition of flora has a negative effect on ecosystem services (ES) of plant communities, like UHI mitigation, water retention potential, landscape connectivity [187] as well as air pollution [75, 134]. The positive correlation between the biodiversity and net primary productivity (NPP) [188], and its relationship with the LAI $[189,190]$ are involved in this phenomenon. The general trend shows that functional traits of plants are more meaningful for the ES than species richness [191], and seems to be also responsible for the ability of flora to capture PM. Manes et al. [192, 193] proved such a relationship between the biodiversity and $\mathrm{PM}_{10}$ removal in Italian cities. The mean values of $\mathrm{PM}_{10}$ deposition per $\mathrm{m}^{2}$ of leaves for various physiognomic-structural vegetation categories (PSVCs) may differ from $0.75 \mathrm{~g} \mathrm{~m}^{-2}$ in beech woods to $1.93 \mathrm{~g} \mathrm{~m}^{-2}$ in holm oak woods [193]. The authors indicated that yearly PM sequestration of highly biodiverse PSVCs, like holm oak woods, relates to their higher LAI or the share of evergreen foliage (of Mediterranean maquis), which can retain PM throughout the year. Another issue is the emission of BVOCs. A highly complex species richness and vertical diversity through the forest canopy is required to prevent leaves from overheating and increasing BVOC production [194].

Biodiversity provides air pollution abatement via various pathways. Plant diversity supports plant community resilience and diminishes plant stresses in difficult urban conditions, via a more effective use of resources. It also improves the water availability in soils by increasing the water retention and microflora activity. All these allow plants to maintain their water balance and stomatal conductance, which influence their capacity to remove airborne PM. Furthermore, improved condition of plants increases their tolerance to pollution stresses [195]. What is more, abundant vegetation mitigates climate, leading to reduced BVOC emissions and, in response, diminished levels of secondary PM. Additional values is included to this effect through enhanced carbon sequestration.

\section{Transgenic plants}

High hopes for improvement in the air purification is put into transgenic plants. The potential of genetically modified plants for degradation of both organic and inorganic (mainly metal, metalloid) pollutants has been widely confirmed in vitro [196]. A few classes of organic xenobiotics can be degraded. They include solvents, explosives, PAHs, PCBs, as well as pesticides and herbicides [197]. Genetic engineering of plants in order to improve their phytoremediation of pollutants involves usually three protocols: over-expression of plant genes engaged in the degradation of organic xenobiotics, transfer of microbial genes, and inoculation of plants with endophytic microorganisms with xenobiotic-degrading potential [198, 199]. Until today, different plant species were subjected to genetic modifications to enable their usage in environmental detoxification, with a special focus on Arabidopsis thaliana (L.) Heynh., tobacco Nicotiana tabacum L., tomato Lycopersicon esculentum Mill., rice Oryza L., alfalfa Medicago sativa $\mathrm{L}$. and various species of cabbage and poplar [199]. Almost all studies in situ were focused on soil and water contaminants removed by the rhizosphere, while the studies on air pollution reduction are scarce. What is more, most of them also relate to the rhizospheric potential for pollution reduction. The first study on the possibility of reducing ambient air pollution with transgenic plants was conducted by Doty et al. [200]. They developed transgenic poplar (Populus tremula L. x Populus alba L.) by overexpressing cytochrome $4502 \mathrm{E} 1$, an enzyme involved in the metabolism of hexachlorocyclohexane $(\mathrm{HCH})$ in plants. The cuttings of 
Table 3 Accumulation of particulate matter on European herbaceous plant leaves (particle $\times \mathrm{mm}^{-1}$ ) in street corridors [152]

\begin{tabular}{llr}
\hline Species & Mean & Max \\
\hline Achillea millefolium & 212.5 & 4233.3 \\
Artemisia vulgaris & 119.2 & 1054.6 \\
Berteroa incana & 172.0 & 2372.2 \\
Chenopodium album & 219.4 & 3210.2 \\
Convolvulus arvensis & 249.3 & 1391.7 \\
Elytrigia repens & 59.3 & 629.6 \\
Erodium cicutarium & 91.3 & 1164.8 \\
Festuca rubra & 13.8 & 74.4 \\
Galinsoga parviflora & 134.7 & 1615.7 \\
Lolium perenne & 79.7 & 676.8 \\
Plantago lanceolata & 52.0 & 391.7 \\
Poa pratensis & 56.4 & 336.1 \\
Polygonum aviculare & 454.9 & 4371.3 \\
Sisymbrium loeselii & 546.0 & 2488.9 \\
Taraxacum officinale & 69.5 & 813.9 \\
Trifolium repens & 38.6 & 150.0 \\
\hline
\end{tabular}

Table 4 Classifying of VOC emitting plant species (measured at $30{ }^{\circ} \mathrm{C}$ leaf temperature and $1,000 \mu \mathrm{mol} \mathrm{m}{ }^{-2} \mathrm{~s}^{-1}$ PPFD) [184]

\begin{tabular}{|c|c|c|c|}
\hline & \multicolumn{3}{|c|}{ Concentration $\left(\mu \mathrm{g} \mathrm{g} \mathrm{DW} W^{-1} h^{-1}\right)$} \\
\hline & Low & Medium & High \\
\hline Isoprene & $<10.0$ & $10.1-30.0$ & $>30.1$ \\
\hline Monoterpenes & $<2$ & $2.1-5.0$ & $>5.1$ \\
\hline Sesquiterpenes & $<0.5$ & $0.6-1.0$ & $>1.1$ \\
\hline Oxygenated VOCs & $<2$ & $2.1-5.0$ & $>5.1$ \\
\hline
\end{tabular}

transgenic poplar achieved about tenfold removal rate of low-weight hydrocarbons (benzene, chloroform and trichloroethylene) from the air, compared to the control. The possibility of degrading high-weight PAHs and other organic pollutants seems to be within reach in the near future. Poplars of different species seem to be a key target for genetic manipulations for pollution abatement purposes, due to their remedial capacity of miscellaneous organic and inorganic pollutants, high effectiveness of photosynthesis, intensive growth potential, and ease of genetic manipulations [201].

\section{Conclusions}

A large progress has been made in using greenery in air pollution reduction. However, there still exist big gaps in our knowledge about this phenomenon. One of the biggest problems is the lack of uniform scales for the amount of captured pollutants, which makes a comprehensive comparison of the most effective species for air pollution reduction difficult. We also still cannot be sure about the traits of leaves which improve PM capture. In spite of this, there is an agreement regarding the benefits of green infrastructure in cities, which is locally expected to reduce the ambient $\mathrm{PM}_{10}$ by $26 \%$ [157]. What is more, green spaces provide numerous profits connected with the climate (like $\mathrm{CO}_{2}$ sequestration and UHI mitigation), biodiversity, as well as to the human health and wellbeing [202]. There are also benefits, that were not known before: a positive effect of green infrastructure on the mortality and morbidity caused by COVID-19 have been observed in recent months [203].

To acquire the most from plants' potential for PM capture, it is crucial to integrate various types of green infrastructure [204], what brings about distinct increase in LAI and capture ability. Nevertheless, there is still room for further progress in employing plants in PM reduction. The most promising expectations are related to species selection, inoculation with endophytic bacteria, and transgenic plants or microorganisms. However, the last solution is regarded controversial and does not always meet social approval, but it may be used in the vicinity of source of pollution, while maintaining spatial isolation. In order to be able to select the appropriate species for PM reduction, their PM abatement potential under local climatic conditions should be taken into consideration as well as their tolerance to stresses and VOC emissions. Inoculation of endophytic bacteria is well-documented in terms of rhizofiltration [86]. Research with the utilization of such bacteria in neutralization of air-originating contaminants is scarce, but proved to be effective $[83,205]$.

\section{Abbreviations \\ AVOCs: Anthropogenic volatile organic compounds; BVOCs: Biogenic volatile organic compounds; GHG: Greenhouse gases; GR: Green roofs; LAl: Leaf area index; MAH: Monocyclic aromatic hydrocarbons; NPP: Net primary productiv- ity; PAH: Polycyclic aromatic hydrocarbons; PCBs: Polychlorinated biphenyls; POP: Persistent organic pollutants; PSVC: Physiognomic-structural vegeta- tion categories; SOA: Secondary organic aerosols; SPRE: Single-pass removal efficiency; UHI: Urban heat island; VOCs: Volatile organic compounds.}

\section{Acknowledgements}

Not applicable.

\section{Authors' contributions}

$\mathrm{KW}$ was a major contributor in writing the manuscript. BRJ conceptualized and supervised the manuscript. All authors read and approved the final manuscript.

\section{Funding}

None.

Availability of data and materials

Not applicable. 


\section{Declarations}

Ethics approval and consent to participate

Not applicable.

\section{Consent for publication}

Not applicable.

\section{Competing interests}

The authors declare that they have no competing interests.

\section{Author details}

${ }^{1}$ Department of Horticulture, Wrocław University of Environmental and Life Sciences, Wrocław, Poland. ${ }^{2}$ Department of Horticulture, College of Agriculture and Life Science, Gyeongsang National University, Jinju 52828, South Korea. ${ }^{3}$ Division of Applied Life Science (BK21 Four), Graduate School, Gyeongsang National University, Jinju 52828, South Korea. ${ }^{4}$ Institute of Agriculture and Life Science, Gyeongsang National University, Jinju, South Korea.

Received: 28 June 2021 Accepted: 22 August 2021

Published online: 25 September 2021

\section{References}

1. Crutzen P (2006) The, "anthropocene." Earth system science in the anthropocene. Berlin, Springer, pp 13-18

2. Steffen W, Grinevald J, Crutzen P, Mcneill J (2011) The anthropocene: Conceptual and historical perspectives. Philos Trans R Soc A Math Phys Eng Sci 369:842-867. https://doi.org/10.1098/rsta.2010.0327

3. Bailey RE, Hatton TJ, Inwood K (2018) Atmospheric pollution, health, and height in late nineteenth century Britain. J Econ Hist 78:1210-1247. https://doi.org/10.1017/S0022050718000578

4. Jain AK, Hayhoe KAS (2007) Global air pollution problems. Handb Atmos Sci Princ Appl 2:339-375. https://doi.org/10.1002/9780470999 318.ch13

5. DellaSala DA, Goldstein MI, Elias S, Jennings B, Lacher TE, Mineau P Pyare $S$. The anthropocene: how the great acceleration is transforming the planet at unprecedented levels, vol. 1-5. Hoboken: Elsevier Inc: 2017. ISBN 9780128096659.

6. Who T, Quality A, Update G, Asia W.H.O.S, Pacific W. Air pollution. 2019; 2: 1-9.

7. Jain AK, Hayhoe KAS (2007) Global air pollution problems. Handb Atmos Sci 2:339-375. https://doi.org/10.1002/9780470999318.ch13

8. World Health Organization (2018) Burden of disease from ambient air pollution for 2016 description of method v5 May 2018. World Heal Organ 2017:6

9. World Health Organization (2019) The power of cities: tackling noncommunicable diseases and road traffic injuries. World Health Organization, Geneva, p 83

10. André N (2005) Air pollution—related illness: effects of particles. Science (80-) 308:804-806

11. Agarwal P, Sarkar M, Chakraborty B, Banerjee T. Phytoremediation of air pollutants: prospects and challenges. Hoboken: Elsevier Inc; 2018. ISBN 9780128139134.

12. Guo L, Turner AG (2014) Impacts of 20th century aerosol emissions on the South Asian monsoon in the CMIP5 models. Atmos Chem Phys Discuss 14:30639-30666. https://doi.org/10.5194/acpd-14-30639-2014

13. He J, Chen K, Xu J (2017) Urban air pollution and control. Encycl Sustain Technol. https://doi.org/10.1016/B978-0-12-409548-9.10182-4

14. WHO (2018) Ambient air quality and health - fact sheet. World Health Organisation, Geneva

15. Selden TM, Song D (1994) Environmental quality and development: Is there a kuznets curve for air pollution emissions? J Environ Econ Manage 27:147-162. https://doi.org/10.1006/jeem.1994.1031

16. Cole MA, Rayner AJ, Bates JM (1997) The environmental Kuznets curve: an empirical analysis. Environ Dev Econ 2:401-416. https://doi. org/10.1017/S1355770X97000211

17. De Pascali P, Bagaini A (2019) Energy transition and urban planning for local development. A critical review of the evolution of integrated spatial and energy planning. Energies 12:1-21. https://doi.org/10 3390/en12010035

18. European Economic and Social Committee. Opinion of the European Economic and Social Committee on 'Communication from the Commission to the European Parliament, the Council, the European Economic and Social Committee and the Committee of the Regions-EU Biodiversity Strategy for 2030-bringing; 2020.

19. Lee BXY, Hadibarata T, Yuniarto A (2020) Phytoremediation mechanisms in air pollution control: a review. Water Air Soil Pollut. https:// doi.org/10.1007/s11270-020-04813-6

20. Filho WL, Icaza LE, Omenche V, Al-Amin AQ (2017) Impacts, strategies and tools to mitigate UHI. A+BE Archit Built Environ. https://doi.org/ 10.7480/abe.2017.20.3462

21. Aflaki A, Mirnezhad M, Ghaffarianhoseini A, Ghaffarianhoseini A, Omrany H, Wang ZH, Akbari H (2017) Urban heat island mitigation strategies: a state-of-the-art review on Kuala Lumpur, Singapore and Hong Kong. Cities 62:131-145. https://doi.org/10.1016/j.cities.2016. 09.003

22. Crippa M, Guizzardi D, Muntean M, Schaaf E, Dentener F, Van AJA, Monni S, Doering U, Olivier JGJ, Pagliari V (2018) Gridded emissions of air pollutants for the period 1970-2012 within EDGAR v4.3.2. Earth Syst Sci Data 10:1987-2013. https://doi.org/10.5194/ essd-10-1987-2018

23. Cofala J, Amann M, Klimont Z, Kupiainen K, Höglund-Isaksson L (2007) Scenarios of global anthropogenic emissions of air pollutants and methane until 2030. Atmos Environ 41:8486-8499. https://doi. org/10.1016/j.atmosenv.2007.07.010

24. Do DH, Walgraeve C, Amare AN, Barai KR, Parao AE, Demeestere K, van Langenhove $\mathrm{H}$ (2015) Airborne volatile organic compounds in urban and industrial locations in four developing countries. Atmos Environ 119:330-338. https://doi.org/10.1016/j.atmosenv.2015.08.065

25. Calfapietra C, Fares S, Manes F, Morani A, Sgrigna G, Loreto F (2013) Role of Biogenic Volatile Organic Compounds (BVOC) emitted by urban trees on ozone concentration in cities: a review. Environ Pollut 183:71-80. https://doi.org/10.1016/j.envpol.2013.03.012

26. Freney E, Sellegri K, Chrit M, Adachi K, Brito J, Waked A, Borbon A, Colomb A, Dupuy R, Pichon JM et al (2018) Aerosol composition and the contribution of SOA formation over Mediterranean forests. Atmos Chem Phys 18:7041-7056. https://doi.org/10.5194/acp-18-7041-2018

27. Heal MR, Hibbs LR, Agius RM, Beverland IJ (2005) Interpretation of variations in fine, coarse and black smoke particulate matter concentrations in a northern European city. Atmos Environ 39:3711-3718. https://doi.org/10.1016/j.atmosenv.2005.03.007

28. Sinha SN (2019) Air pollution from solid fuels. Encycl Environ Heal. https://doi.org/10.1016/B978-0-12-409548-9.11266-7

29. Kappos AD, Bruckmann P, Eikmann T, Englert N, Heinrich U, Höppe P, Koch E, Krause GHM, Kreyling WG, Rauchfuss K et al (2004) Health effects of particles in ambient air. Int J Hyg Environ Health 207:399_ 407. https://doi.org/10.1078/1438-4639-00306

30. Park SS, Kim YJ, Kang CH (2007) Polycyclic aromatic hydrocarbons in bulk PM2.5 and size-segregated aerosol particle samples measured in an urban environment. Environ Monit Assess 128:231-240. https:// doi.org/10.1007/s10661-006-9308-4

31. Kampa M, Castanas E (2008) Human health effects of air pollution. Environ Pollut 151:362-367. https://doi.org/10.1016/j.envpol.2007.06. 012

32. de Jesus AL, Rahman MM, Mazaheri M, Thompson H, Knibbs LD, Jeong C, Evans G, Nei W, Ding A, Qiao L et al (2019) Ultrafine particles and PM2.5 in the air of cities around the world: are they representative of each other? Environ Int 129:118-135. https://doi.org/10. 1016/j.envint.2019.05.021

33. Fiore AM, Naik V, Spracklen DV, Steiner A, Unger N, Prather M, Bergmann D, Cameron-Smith PJ, Cionni I, Collins WJ et al (2012) Cationic polymers and their therapeutic potential. Chem Soc Rev 41:66636683. https://doi.org/10.1039/c2cs35095e

34. Avino P, Casciardi S, Fanizza C, Manigrasso M (2011) Deep investigation of Ultrafine particles in urban air. Aerosol Air Qual Res 11:654-663. https://doi.org/10.4209/aagr.2010.10.0086 
35. Ashraf MA (2017) Persistent organic pollutants (POPs): a global issue, a global challenge. Environ Sci Pollut Res 24:4223-4227. https://doi.org/ 10.1007/s11356-015-5225-9

36. Bogdal C, Scheringer M, Abad E, Abalos M, Van Bavel B, Hagberg J, Fiedler H (2013) Worldwide distribution of persistent organic pollutants in air, including results of air monitoring by passive air sampling in five continents. TrAC Trends Anal Chem 46:150-161. https://doi.org/10. 1016/j.trac.2012.05.011

37. De Nicola F, Alfani A, Maisto G (2014) Polycyclic aromatic hydrocarbon contamination in an urban area assessed by Quercus ilex leaves and soil. Environ Sci Pollut Res 21:7616-7623. https://doi.org/10.1007/ s11356-014-2665-6

38. Babula P, Adam V, Opatrilova R, Zehnalek J, Havel L, Kizek R (2008) Uncommon heavy metals, metalloids and their plant toxicity: a review. Environ Chem Lett 6:189-213. https://doi.org/10.1007/ s10311-008-0159-9

39. Duruibe JO, Ogwuegbu MOC (2007) Egwurugwu Heavy metal pollution and human biotoxic effects. Int J Phys Sci 2:112-118

40. Tiwary A, Williams ID, Heidrich O, Namdeo A, Bandaru V, Calfapietra C (2016) Development of multi-functional streetscape green infrastructure using a performance index approach. Environ Pollut 208:209-220. https://doi.org/10.1016/j.envpol.2015.09.003

41. Ekblad A, Bastviken D (2019) Deforestation releases old carbon. Nat Geosci. https://doi.org/10.1038/s41561-019-0394-7

42. Pendrill F, Persson UM, Godar J, Kastner T, Moran D, Schmidt S, Wood R (2019) Agricultural and forestry trade drives large share of tropical deforestation emissions. Glob Environ Chang 56:1-10. https://doi.org/ 10.1016/j.gloenvcha.2019.03.002

43. FAO (2018) The state of the world's forests 2018. Forest pathways to sustainable development. FAO, Rome

44. Niinemets Ü (2010) Mild versus severe stress and BVOCs: thresholds, priming and consequences. Trends Plant Sci 15:145-153

45. Ghirardo A, Xie J, Zheng X, Wang Y, Grote R, Block K, Wildt J, Mentel T, Kiendler-Scharr A, Hallquist M et al (2016) Urban stress-induced biogenic VOC emissions and SOA-forming potentials in Beijing. Atmos Chem Phys 16:2901-2920. https://doi.org/10.5194/acp-16-2901-2016

46. Laothawornkitkul J, Taylor JE, Paul ND, Hewitt CN (2009) Biogenic volatile organic compounds in the Earth system: Tansley review. New Phytol 183:27-51. https://doi.org/10.1111/j.1469-8137.2009.02859.x

47. Steinbrecher R, Smiatek G, Köble R, Seufert G, Theloke J, Hauff K, Cicciol P, Vautard R, Curci G (2009) Intra- and inter-annual variability of VOC emissions from natural and semi-natural vegetation in Europe and neighbouring countries. Atmos Environ 43:1380-1391. https:/doi.org/ 10.1016/j.atmosenv.2008.09.072

48. Guenther AB, Jiang $X$, Heald CL, Sakulyanontvittaya T, Duhl T, Emmons LK, Wang X (2012) The model of emissions of gases and aerosols from nature version 2.1 (MEGAN21): an extended and updated framework for modeling biogenic emissions. Geosci Model Dev 5:1471-1492. https://doi.org/10.5194/gmd-5-1471-2012

49. Kvesitadze E, Sadunishvili T, Kvesitadze G (2009) Mechanisms of organic contaminants uptake and degradation in plants. Int J Biol Biomed Eng 3:361-371

50. Paris A, Ledauphin J, Poinot P, Gaillard JL (2018) Polycyclic aromatic hydrocarbons in fruits and vegetables: origin, analysis, and occurrence. Environ Pollut 234:96-106. https://doi.org/10.1016/j.envpol.2017.11.028

51. El Amrani A, Dumas AS, Wick LY, Yergeau E, Berthomé R (2015) "Omics" insights into $\mathrm{PAH}$ degradation toward improved green remediation biotechnologies. Environ Sci Technol 49:11281-11291. https://doi.org/ 10.1021/acs.est.5b01740

52. Baldacchini C, Castanheiro A, Maghakyan N, Sgrigna G, Verhelst J, Alonso R, Amorim JH, Bellan P, Bojović DD, Breuste J et al (2017) How does the amount and composition of PM deposited on Platanus acerifolia leaves change across different cities in Europe? Environ Sci Technol 51:1147-1156. https://doi.org/10.1021/acs.est.6b04052

53. Wang L, Gong H, Liao W, Wang Z (2015) Accumulation of particles on the surface of leaves during leaf expansion. Sci Total Environ 532:420-434. https://doi.org/10.1016/j.scitotenv.2015.06.014

54. Jin EJ, Yoon JH, Bae EJ, Jeong BR, Yong SH, Choi MS (2021) Particulate matter removal ability of ten evergreen trees planted in Korea urban greening. Forests 12:438. https://doi.org/10.3390/f12040438
55. Fernandez V, Eichert T (2009) Uptake of hydrophilic solutes through plant leaves: current state of knowledge and perspectives of foliar fertilization. CRC Crit Rev Plant Sci 28:36-68. https://doi.org/10.1080/ 07352680902743069

56. Janhäll S (2015) Review on urban vegetation and particle air pollution-deposition and dispersion. Atmos Environ 105:130-137. https:// doi.org/10.1016/j.atmosenv.2015.01.052

57. Liang D, Ma C, Wang YQ, Wang YJ, Chen-xi Z (2016) Quantifying PM2.5 capture capability of greening trees based on leaf factors analyzing. Environ Sci Pollut Res 23:21176-21186. https://doi.org/10.1007/ s11356-016-7687-9

58. Räsänen JV, Holopainen T, Joutsensaari J, Ndam C, Pasanen P, Rinnan $\AA$, Kivimäenpää M (2013) Effects of species-specific leaf characteristics and reduced water availability on fine particle capture efficiency of trees. Environ Pollut 183:64-70. https://doi.org/10.1016/j.envpol.2013.05.015

59. Tomson M, Kumar P, Barwise Y, Perez P, Forehead H, French K, Morawska L, Watts JF (2021) Green infrastructure for air quality improvement in street canyons. Environ Int 146:106288. https://doi.org/10.1016/j.envint. 2020.106288

60. Terzaghi E, Wild E, Zacchello G, Cerabolini BEL, Jones KC, Di Guardo A (2013) Forest filter effect: role of leaves in capturing/releasing air particulate matter and its associated PAHs. Atmos Environ 74:378-384. https://doi.org/10.1016/j.atmosenv.2013.04.013

61. Beckett KP, Freer-Smith PH, Taylor G (2000) Particulate pollution capture by urban trees: effect of species and windspeed. Glob Chang Biol 6:995-1003. https://doi.org/10.1046/j.1365-2486.2000.00376.x

62. Freer-Smith PH, Beckett KP, Taylor G (2005) Deposition velocities to Sorbus aria, Acer campestre, Populus deltoides x trichocarpa "Beaupré", Pinus nigra and $\times$ Cupressocyparis leylandii for coarse, fine and ultra-fine particles in the urban environment. Environ Pollut 133:157-167. https:// doi.org/10.1016/j.envpol.2004.03.031

63. Perini K, Ottelé M, Giulini S, Magliocco A, Roccotiello E (2017) Quantification of fine dust deposition on different plant species in a vertical greening system. Ecol Eng 100:268-276. https://doi.org/10.1016/j.ecole ng.2016.12.032

64. Weerakkody U, Dover JW, Mitchell P, Reiling K, Tomson M, Kumar P, Barwise $Y$, Perez P, Forehead $H$, French K et al (2019) Evaluating the impact of individual leaf traits on atmospheric particulate matter accumulation using natural and synthetic leaves. Urban For Urban Green 10:119-129. https://doi.org/10.3791/58026

65. Fernández V, Sancho-Knapik D, Guzmán P, Peguero-Pina JJ, Gil L, Karabourniotis G, Khayet M, Fasseas C, Heredia-Guerrero JA, Heredia A et al (2014) Wettability, polarity, and water absorption of holm oak leaves: effect of leaf side and age. Plant Physiol 166:168-180. https://doi.org/ 10.1104/pp.114.242040

66. Samson R, Grote R, Calfapietra C, Cariñanos P, Fares S, Paoletti E, Tiwary A. Urban trees and their relation to air pollution. In: Pearlmutter $D$ Calfapietra C, Samson R, Orien L, Ostoić S, Ilvija K, Sanesi G, Amo RA Del, editors. The urban forest Cultivating green infrastructure for people and the environment. Springer, 2017; p. 21-30 ISBN 978-3-319-50279-3.

67. Sgrigna G, Sæbø A, Gawronski S, Popek R, Calfapietra C (2015) Particulate Matter deposition on Quercus ilex leaves in an industrial city of central Italy. Environ Pollut 197:187-194. https://doi.org/10.1016/j. envpol.2014.11.030

68. Wang L, Gao S, Liu L, Ha S (2006) Atmospheric particle-retaining capability of eleven garden plant species in Beijing. Chin J Appl Eco 17:597-601

69. Sgrigna G, Baldacchini C, Dreveck S, Cheng Z, Calfapietra C (2020) Relationships between air particulate matter capture efficiency and leaf traits in twelve tree species from an Italian urban-industrial environment. Sci Total Environ 718:137310. https://doi.org/10.1016/j.scitotenv. 2020.137310

70. Di Guardo A, Zaccara S, Cerabolini B, Acciarri M, Terzaghi G, Calamari D (2003) Conifer needles as passive biomonitors of the spatial and temporal distribution of DDT from a point source. Chemosphere 52:789-797. https://doi.org/10.1016/S0045-6535(03)00256-X

71. Dzierzanowski K, Popek R, Gawrońska H, Saebø A, Gawroński SW (2011) Deposition of particulate matter of different size fractions on leaf surfaces and in waxes of urban forest species. Int J Phytoremediation 13:1037-1046. https://doi.org/10.1080/15226514.2011.552929 
72. Jouraeva VA, Johnson DL, Hassett JP, Nowak DJ (2002) Differences in accumulation of PAHs and metals on leaves of Tilia X echlora and pyrus Calleryana. Environ Pollut 120:331-338. https://doi.org/10.1016/S02697491(02)00121-5

73. Reischl A, Reissinger M, Thoma H, Hutzinger O (1989) Accumulation of organic air constituents by plant surfaces: Part IV. Plant surfaces: a sampling system for atmospheric polychlorodibenzo-p-dioxin (PCDD) and polychlorodibenzo-p-furan (PCDF). Chemosphere 18:561-568. https:// doi.org/10.1016/0045-6535(89)90167-7

74. Riederer $M$, Schreiber $L$ (2001) Protecting against water loss: analysis of the barrier properties of plant cuticles. Proc J Exp Bot 52:2023-2032

75. Chen L, Liu C, Zou R, Yang M, Zhang Z (2016) Experimental examination of effectiveness of vegetation as bio-filter of particulate matters in the urban environment. Environ Pollut 208:198-208. https://doi.org/10. 1016/j.envpol.2015.09.006

76. Yutthammo C, Thongthammachat N, Pinphanichakarn P, Luepromchai E (2010) Diversity and activity of pah-degrading bacteria in the phyllosphere of ornamental plants. Microb Ecol 59:357-368. https://doi.org/ 10.1007/s00248-009-9631-8

77. Jiang Y, Yuan T (2017) Public perceptions and preferences for wildflower meadows in Beijing, China. Urban For Urban Green. https://doi.org/10. 1016/j.ufug.2017.07.004

78. Ostrem Loss EM, Yu JH (2018) Bioremediation and microbial metabolism of benzo(a)pyrene. Mol Microbiol 109:433-444. https://doi.org/10. 1111/mmi.14062

79. Wei X, Lyu S, Yu Y, Wang Z, Liu H, Pan D, Chen J (2017) Phylloremediation of air pollutants: exploiting the potential of plant leaves and leafassociated microbes. Front Plant Sci 8:1-23. https://doi.org/10.3389/ fpls.2017.01318

80. Undugoda LJ, Kannangara S, Sirisena DM (2016) Aromatic hydrocarbon degrading fungi inhabiting the phyllosphere of ornamental plants on roadsides of urban areas in Sri Lanka. J Bioremediation Biodegrad. https://doi.org/10.4172/2155-6199.1000328

81. Waight K, Pinyakong O, Luepromchai E (2007) Degradation of phenanthrene on plant leaves by phyllosphere bacteria. J Gen Appl Microbiol 53:265-272. https://doi.org/10.2323/jgam.53.265

82. Franzetti A, Gandolfi I, Bestetti G, Padoa Schioppa E, Canedoli C, Brambilla D, Cappelletti D, Sebastiani B, Federici E, Papacchini M et al (2020) Plant-microorganisms interaction promotes removal of air pollutants in Milan (Italy) urban area. J Hazard Mater. https://doi.org/10.1016/j.jhazm at.2019.121021

83. Wang J, Liu J, Ling W, Huang Q, Gao Y (2017) Composite of PAH-degrading endophytic bacteria reduces contamination and health risks caused by PAHs in vegetables. Sci Total Environ 598:471-478. https://doi.org/ 10.1016/j.scitotenv.2017.04.126

84. Festa S, Coppotelli BM, Madueño L, Loviso CL, Macchi M, Neme Tauil RM, Valacco MP, Morelli IS (2017) Assigning ecological roles to the populations belonging to a phenanthrene-degrading bacterial consortium using omic approaches. PLoS ONE 12:1-21. https://doi.org/10. 1371/journal.pone.0184505

85. Bringel F, Couée I (2015) Pivotal roles of phyllosphere microorganisms at the interface between plant functioning and atmospheric trace gas dynamics. Front Microbiol 6:1-14. https://doi.org/10.3389/fmicb.2015. 00486

86. Weyens N, Thijs S, Popek R, Witters N, Przybysz A, Espenshade J, Gawronska H, Vangronsveld J, Gawronski SW (2015) The role of plantmicrobe interactions and their exploitation for phytoremediation of air pollutants. Int J Mol Sci 16:25576-25604. https://doi.org/10.3390/ijms1 61025576

87. Sánchez-López AS, González-Chávez M, Del Carmen A, SolísDomínguez FA, Carrillo-González R, Rosas-Saito GH (2018) Leaf epiphytic bacteria of plants colonizing mine residues: possible exploitation for remediation of air pollutants. Front Microbiol 9:1-16. https://doi.org/ 10.3389/fmicb.2018.03028

88. Ghosal D, Ghosh S, Dutta TK, Ahn Y (2016) Current state of knowledge in microbial degradation of polycyclic aromatic hydrocarbons (PAHs): a review. Front Microbiol 7:1369. https://doi.org/10.3389/fmicb.2016. 01369

89. Kannangara S, Undugoda L, Rajapaksha N (2016) Depolymerizing activities of aromatic hydrocarbon degrading phyllosphere fungi in Sri Lanka.
J Bioremediation Biodegrad. https://doi.org/10.4172/2155-6199.10003 72

90. Pagé AP, Yergeau É, Greer CW (2015) Salix purpurea stimulates the expression of specific bacterial xenobiotic degradation genes in a soil contaminated with hydrocarbons. PLoS ONE 10:1-16. https://doi.org/ 10.1371/journal.pone.0132062

91. Qiu L, Liu F, Zhang X, Gao T (2019) Difference of airborne particulate matter concentration in urban space with different green coverage rates in Baoji, China. Int J Environ Res Public Health. https://doi.org/10. 3390/ijerph16081465

92. Litschike T, Kuttler W (2008) On the reduction of urban particle concentration by vegetation - a review. Meteorol Zeitschrift 17:229-240. https://doi.org/10.1127/0941-2948/2008/0284

93. Morakinyo TE, Lam YF, Hao S (2016) Evaluating the role of green infrastructures on near-road pollutant dispersion and removal: Modelling and measurement. J Environ Manage 182:595-605. https://doi.org/10. 1016/j.jenvman.2016.07.077

94. Pugh TAM, MacKenzie AR, Whyatt JD, Hewitt CN (2012) Effectiveness of green infrastructure for improvement of air quality in urban street canyons. Environ Sci Technol 46:7692-7699. https://doi.org/10.1021/ es300826w

95. Li Z, Guo J, Ding A, Liao H, Liu J, Sun Y, Wang T, Xue H, Zhang H, Zhu B (2017) Aerosol and boundary-layer interactions and impact on air quality. Natl Sci Rev 4:810-833. https://doi.org/10.1093/nsr/nwx117

96. Vos PEJ, Maiheu B, Vankerkom J, Janssen S (2013) Improving local air quality in cities: to tree or not to tree? Environ Pollut 183:113-122. https://doi.org/10.1016/j.envpol.2012.10.021

97. Hewitt CN, Ashworth K, MacKenzie AR (2020) Using green infrastructure to improve urban air quality (GI4AQ). Ambio 49:62-73. https://doi.org/ 10.1007/s13280-019-01164-3

98. Xu X, Zhang Z, Bao L, Mo L, Yu X, Fan D, Lun X (2017) Influence of rainfall duration and intensity on particulate matter removal from plant leaves. Sci Total Environ 609:11-16. https://doi.org/10.1016/j.scitotenv.2017.07. 141

99. Yan G, Cong L, Zhai J, Wu Y, Dai L, Zhang Z (2019) Particle removal in polluted cities: Insights from the wash-off process dynamics for different wetland plants. J Environ Manage 245:114-121. https://doi.org/10. 1016/j.jenvman.2019.05.085

100. Blanusa T, Fantozzi F, Monaci F, Bargagli R (2015) Leaf trapping and retention of particles by holm oak and other common tree species in Mediterranean urban environments. Urban For Urban Green 14:1095-1101. https://doi.org/10.1016/j.ufug.2015.10.004

101. Zheng G, Li P (2019) Resuspension of settled atmospheric particulate matter on plant leaves determined by wind and leaf surface characteristics. Environ Sci Pollut Res 26:19606-19614. https://doi.org/10.1007/ s11356-019-05241-8

102. Kim Y, Wellum G, Mello K, Strawhecker KE, Thoms R, Giaya A, Wyslouzil BE (2016) Effects of relative humidity and particle and surface properties on particle resuspension rates. Aerosol Sci Technol 50:339-352. https://doi.org/10.1080/02786826.2016.1152350

103. Benedict MA, MacMahon ET (2002) Green infrastructure: Smart conservation for the 21st century. Renew Resour J 20:12-17

104. Skar SLG, Pineda-Martos R, Timpe A, Pölling B, Bohn K, Külvik M, Delgado C, Pedras CMG, Paço TA, Ćujić M et al (2020) Urban agriculture as a keystone contribution towards securing sustainable and healthy development for cities in the future. Blue-Green Syst 2:1-27. https://doi org/10.2166/bgs.2019.931

105. Habitata U (2021) The strategic plan 2020-2023. Habitat U, Milton Keynes

106. Oberndorfer E, Lundholm J, Bass B, Coffman RR, Doshi H, Dunnett N, Gaffin S, Köhler M, Liu KKY, Rowe B (2007) Green roofs as urban ecosystems: ecological structures, functions, and services. Bioscience 57:823-833

107. Speak AF, Rothwell JJ, Lindley SJ, Smith CL (2012) Urban particulate pollution reduction by four species of green roof vegetation in a UK city. Atmos Environ 61:283-293. https://doi.org/10.1016/j.atmosenv.2012.07. 043

108. Gourdji S (2018) Review of plants to mitigate particulate matter, ozone as well as nitrogen dioxide air pollutants and applicable 
recommendations for green roofs in Montreal, Quebec. Environ Pollut 241:378-387. https://doi.org/10.1016/.envpol.2018.05.053

109. Yang J, Yu Q, Gong P (2008) Quantifying air pollution removal by green roofs in Chicago. Atmos Environ 42:7266-7273. https://doi.org/10.1016/j. atmosenv.2008.07.003

110. Sicard P, Agathokleous E, Araminiene V, Carrari E, Hoshika Y, De Marco A, Paoletti E (2018) Should we see urban trees as effective solutions to reduce increasing ozone levels in cities? Environ Pollut 243:163-176. https://doi.org/10.1016/.jenvpol.2018.08.049

111. Grant G, Gedge D. Living Roofs and Walls from policy to practice. London; 2019.

112. Weerakkody U, Dover JW, Mitchell P, Reiling K (2018) Quantification of the traffic-generated particulate matter capture by plant species in a living wall and evaluation of the important leaf characteristics. Sci Total Environ 635:1012-1024. https://doi.org/10.1016/j.scitotenv.2018.04.106

113. Bandehali S, Miri T, Onyeaka H, Kumar P (2021) Current state of indoor air phytoremediation using potted plants and green walls. Atmosphere (Basel) 12:473. https://doi.org/10.3390/atmos12040473

114. Pettit T, Irga PJ, Torpy FR (2020) The evolution of botanical biofilters: developing practical phytoremediation of air pollution for the built environment. iCRBE Procedia 1:116-129. https://doi.org/10.32438/icrbe. 202012

115. Pettit T, Irga P, Torpy F (2018) Towards practical indoor air phytoremediation: a review. Chemosphere 208:960-974

116. Meier R, Schindler C, Eeftens M, Aguilera I, Ducret-Stich RE, Ineichen A, Davey M, Phuleria HC, Probst-Hensch N, Tsai MY et al (2015) Modeling indoor air pollution of outdoor origin in homes of SAPALDIA subjects in Switzerland. Environ Int 82:85-91. https://doi.org/10.1016/j.envint.2015. 05.013

117. Irga PJ, Pettit T, Irga RF, Paull NJ, Douglas ANJ, Torpy FR (2019) Does plant species selection in functional active green walls influence VOC phytoremediation efficiency? Environ Sci Pollut Res 26:12851-12858. https://doi. org/10.1007/s11356-019-04719-9

118. Pettit T, Irga PJ, Abdo P, Torpy FR (2017) Do the plants in functional green walls contribute to their ability to filter particulate matter? Build Environ 125:299-307. https://doi.org/10.1016/j.buildenv.2017.09.004

119. Pettit T, Irga PJ, Torpy FR (2020) The botanical biofiltration of elevated air pollution concentrations associated the Black Summer wildfire natural disaster. J Hazard Mater Lett 1:100003. https://doi.org/10.1016/j.hazl.2020. 100003

120. Torpy FR, Irga PJ, Burchett MD (2015) Reducing indoor air pollutants through biotechnology. Biotechnologies and biomimetics for civil engineering. Springer, Berlin, pp 181-210

121. Aydogan A, Montoya LD (2011) Formaldehyde removal by common indoor plant species and various growing media. Atmos Environ 45:2675-2682. https://doi.org/10.1016/j.atmosenv.2011.02.062

122. Torpy F, Zavattaro M (2018) Bench-study of green-wall plants for indoor air pollution reduction. J Living Archit 5:1-15. https://doi.org/10.46534/ jliv.2018.05.01.001

123. Lefevre GH, Hozalski RM, Novak PJ (2013) Root exudate enhanced contaminant desorption: an abiotic contribution to the rhizosphere effect. Environ Sci Technol 47:11545-11553. https://doi.org/10.1021/es402446v

124. Orwell RL, Wood RL, Tarran J, Torpy F, Burchett MD (2004) Removal of benzene by the indoor plant/substrate microcosm and implications for air quality. Water Air Soil Pollut 157:193-207. https://doi.org/10.1023/B: WATE.0000038896.55713.5b

125. Kraakman NJR, González-Martín J, Pérez C, Lebrero R, Muñoz R (2021) Recent advances in biological systems for improving indoor air quality. Rev Environ Sci Biotechnol 20:363-387. https://doi.org/10.1007/ s11157-021-09569-X

126. Li C, Huang Y, Guo H, Wu G, Wang Y, Li W, Cui L (2019) The concentrations and removal effects of PM10 and PM2.5 on a Wetland in Beijing. Sustain 11:1-15. https://doi.org/10.3390/su11051312

127. Liu Y, Wu J, Yu D, Ma Q (2018) The relationship between urban form and air pollution depends on seasonality and city size. Environ Sci Pollut Res 25:15554-15567. https://doi.org/10.1007/s11356-018-1743-6

128. Rentz JA, Alvarez PJJ, Schnoor JL (2005) Benzo[a]pyrene co-metabolism in the presence of plant root extracts and exudates: Implications for phytoremediation. Environ Pollut 136:477-484. https://doi.org/10.1016/j. envpol.2004.12.034
129. Agrawal M, Singh J (2000) Impact of coal power plant emission on the foliar elemental concentrations in plants in a low rainfall tropical region. Environ Monit Assess 60:261-282. https://doi.org/10.1023/A:1006135317 896

130. Jamal Q, Durani P, Khan K (2013) Heavy metals accumulation and their toxic effects: review. J Bio-Mol Sci 1:27-36

131. Adriano DC. Trace elements in the terrestrial environment. Springer Science \& Business Media; 2013. ISBN 3540961585.

132. Shahid M, Natasha, Dumat C, Niazi NK, Xiong TT, Farooq ABU, Khalid S (2021) Ecotoxicology of heavy metal(loid)-enriched particulate matter: foliar accumulation by plants and health impacts. Reviews of environmental contamination and toxicology, vol 253. Springer, Berlin, pp $65-113$

133. World Health Organization Evaluation of certain food additive and contaminants. In: Proceedings of the World Health Organization technical report series; 2011.

134. Lăcătuşu R, Răuță C, Cârstea S, Ghelase I (1996) Soil-plant-man relationships in heavy metal polluted areas in Romania. Appl Geochem 11:105-107. https://doi.org/10.1016/0883-2927(95)00101-8

135. Park M, Joo HS, Lee K, Jang M, Kim SD, Kim I, Borlaza LJS, Lim H, Shin H, Chung KH et al (2018) Differential toxicities of fine particulate matters from various sources. Sci Rep 8:1-11. https://doi.org/10.1038/ s41598-018-35398-0

136. Uzu G, Sobanska S, Sarret G, Munoz M, Dumat C (2010) Foliar lead uptake by lettuce exposed to atmospheric fallouts: Raman imaging study. Environ Sci Technol 44:1036-1042. https://doi.org/10.1063/1.3482642

137. Rai PK, Lee SS, Zhang M, Tsang YF, Kim KH (2019) Heavy metals in food crops: health risks, fate, mechanisms, and management. Environ Int 125:365-385. https://doi.org/10.1016/j.envint.2019.01.067

138. Shahid M, Dumat C, Khalid S, Schreck E, Xiong T, Niazi NK (2017) Foliar heavy metal uptake, toxicity and detoxification in plants: a comparison of foliar and root metal uptake. J Hazard Mater 325:36-58. https://doi.org/ 10.1016/j.jhazmat.2016.11.063

139. Natasha, Shahid M, Khalid S (2020) Foliar application of lead and arsenic solutions to Spinacia oleracea: biophysiochemical analysis and risk assessment. Environ Sci Pollut Res 27:39763-39773. https://doi.org/10.1007/ s11356-019-06519-7

140. Cheema Al, Liu G, Yousaf B, Abbas Q, Zhou H (2020) A comprehensive review of biogeochemical distribution and fractionation of lead isotopes for source tracing in distinct interactive environmental compartments. Sci Total Environ 719:135658. https://doi.org/10.1016/j.scitotenv.2019. 135658

141. Noh K, Thi LT, Jeong BR (2019) Particulate matter in the cultivation area may contaminate leafy vegetables with heavy metals above safe levels in Korea. Environ Sci Pollut Res 26:25762-25774. https://doi.org/10.1007/ s1 1356-019-05825-4

142. Xiong TT, Leveque T, Austruy A, Goix S, Schreck E, Dappe V, Sobanska S, Foucault Y, Dumat C (2014) Foliar uptake and metal(loid) bioaccessibility in vegetables exposed to particulate matter. Environ Geochem Health 36:897-909. https://doi.org/10.1007/s10653-014-9607-6

143. Azuma H, Toyota M, Asakawa Y, Kawano S (1996) Naphthalene-a constituent of Magnolia flowers. Phytochemistry 42:999-1004. https://doi. org/10.1016/0031-9422(96)00082-9

144. Krauss M, Wilcke W, Martius C, Bandeira AG, Garcia MVB, Amelung W (2005) Atmospheric versus biological sources of polycyclic aromatic hydrocarbons (PAHs) in a tropical rain forest environment. Environ Pollut 135:143-154. https://doi.org/10.1016/j.envpol.2004.09.012

145. Chen Y, Zhang F, Zhang J, Zhou M, Li F, Liu X (2018) Accumulation characteristics and potential risk of PAHs in vegetable system grow in home garden under straw burning condition in Jilin, Northeast China. Ecotoxicol Environ Saf 162:647-654. https://doi.org/10.1016/j.ecoenv. 2018.06.082

146. Wang L, Li C, Jiao B, Li Q, Su H, Wang J, Jin F (2018) Halogenated and parent polycyclic aromatic hydrocarbons in vegetables: levels, dietary intakes, and health risk assessments. Sci Total Environ 616-617:288-295. https://doi.org/10.1016/i.scitotenv.2017.10.336

147. Jia J, Bi C, Zhang J, Jin X, Chen Z (2018) Characterization of polycyclic aromatic hydrocarbons (PAHs) in vegetables near industrial areas of Shanghai, China: sources, exposure, and cancer risk. Environ Pollut 241:750-758. https://doi.org/10.1016/j.envpol.2018.06.002 
148. Ashraf MW, Salam A (2012) Polycyclic aromatic hydrocarbons (pahs) in vegetables and fruits produced in Saudi Arabia. Bull Environ Contam Toxicol 88:543-547. https://doi.org/10.1007/s00128-012-0528-8

149. Nowak DJ, Hirabayashi S, Bodine A, Greenfield E (2014) Tree and forest effects on air quality and human health in the United States. Environ Pollut 193:119-129. https://doi.org/10.1016/j.envpol.2014.05.028

150. Przybysz A, Nersisyan G, Gawroński SW (2019) Removal of particulate matter and trace elements from ambient air by urban greenery in the winter season. Environ Sci Pollut Res 26:473-482. https://doi.org/10.1007/ s11356-018-3628-0

151. Liu J, Zhu L, Wang H, Yang Y, Liu J, Qiu D, Ma W, Zhang Z, Liu J (2016) Dry deposition of particulate matter at an urban forest, wetland and lake surface in Beijing. Atmos Environ 125:178-187. https://doi.org/10.1016/j. atmosenv.2015.11.023

152. Weber F, Kowarik I, Säumel I (2014) Herbaceous plants as filters: immobilization of particulates along urban street corridors. Environ Pollut 186:234-240. https://doi.org/10.1016/j.envpol.2013.12.011

153. McPherson EG, Nowak D, Heisler G, Grimmond S, Souch C, Grant R, Rowntree R (1997) Quantifying urban forest structure, function, and value: the Chicago Urban Forest Climate Project. Urban Ecosyst 1:49-61. https://doi.org/10.1023/A:1014350822458

154. Nowak DJ, Crane DE, Stevens JC (2006) Air pollution removal by urban trees and shrubs in the United States. Urban For Urban Green 4:115-123. https://doi.org/10.1016/j.ufug.2006.01.007

155. Tallis H, Ricketts TH, Daily GC, Polasky S. Natural capital: theory and practice of mapping ecosystem services—oxford scholarship. Oxford Scholarsh. Online; 2013.

156. Escobedo FJ, Nowak DJ (2009) Spatial heterogeneity and air pollution removal by an urban forest. Landsc Urban Plan 90:102-110. https://doi. org/10.1016/j.landurbplan.2008.10.021

157. McDonald AG, Bealey WJ, Fowler D, Dragosits U, Skiba U, Smith R Donovan RG, Brett HE, Hewitt CN, Nemitz E (2007) Quantifying the effect of urban tree planting on concentrations and depositions of PM10 in two UK conurbations. Atmos Environ 41:8455-8467. https://doi.org/10.1016/j. atmosenv.2007.07.025

158. Setälä H, Viippola V, Rantalainen AL, Pennanen A, Yli-Pelkonen V (2013) Does urban vegetation mitigate air pollution in northern conditions? Environ Pollut 183:104-112. https://doi.org/10.1016/j.envpol.2012.11.010

159. Sæbø A, Popek R, Nawrot B, Hanslin HM, Gawronska H, Gawronski SW (2012) Plant species differences in particulate matter accumulation on leaf surfaces. Sci Total Environ 427-428:347-354. https://doi.org/10. 1016/j.scitotenv.2012.03.084

160. Amini Parsa V, Salehi E, Yavari A (2020) Improving the provision of ecosystem services from urban forest by integrating the species' potential environmental functions in tree selecting process. Landsc Ecol Eng 16:23-37. https://doi.org/10.1007/s11355-019-00401-x

161. Shen J, Tang A, Liu X, Kopsch J, Fangmeier A, Goulding K, Zhang F (2011) Impacts of pollution controls on air quality in Beijing during the 2008 olympic games. J Environ Qual 40:37-45. https://doi.org/10.2134/jeq20 10.0360

162. Popek R, Gawrońska H, Wrochna M, Gawroński SW, Saebø A (2013) Particulate matter on foliage of 13 woody species: deposition on surfaces and phytostabilisation in waxes-a 3-year study. Int J Phytoremediation 15:245-256. https://doi.org/10.1080/15226514.2012.694498

163. Beckett KP, Freer-Smith P, Taylor G (2000) Effective tree species for local air quality management. J Arboric 25:12-19

164. Guerrero-Leiva N, Castro SA, Rubio MA, Ortiz-Calderón C (2016) Retention of atmospheric particulate by three woody ornamental species in Santiago, Chile. Water Air Soil Pollut 227:1-9. https://doi.org/10.1007/ s1 1270-016-3124-4

165. Liu J, Zhai J, Zhu L, Yang Y, Liu J, Zhang Z (2017) Particle removal by vegetation: comparison in a forest and a wetland. Environ Sci Pollut Res 24:1597-1607. https://doi.org/10.1007/s11356-016-7790-y

166. Li X, Zhang T, Sun F, Song X, Zhang Y, Huang F, Yuan C, Yu H, Zhang G, Qi F et al (2021) The relationship between particulate matter retention capacity and leaf surface micromorphology of ten tree species in Hangzhou China. Sci Total Environ 771:144812. https://doi.org/10.1016/j.scitotenv. 2020.144812

167. Muhammad S, Wuyts K, Samson R (2019) Atmospheric net particle accumulation on 96 plant species with contrasting morphological and anatomical leaf characteristics in a common garden experiment. Atmos Environ 202:328-344. https://doi.org/10.1016/.atmosenv.2019.01.015

168. Mo L, Ma Z, Xu Y, Sun F, Lun X, Liu X, Chen J, Yu X (2015) Assessing the capacity of plant species to accumulate particulate matter in Beijing, China. PLoS ONE. https://doi.org/10.1371/journal.pone.0140664

169. Shi J, Zhang G, An H, Yin W, Xia X (2017) Quantifying the particulate matter accumulation on leaf surfaces of urban plants in Beijing, China. Atmos Pollut Res 8:836-842. https://doi.org/10.1016/j.apr.2017.01.011

170. Leonard RJ, McArthur C, Hochuli DF (2016) Particulate matter deposition on roadside plants and the importance of leaf trait combinations. Urban For Urban Green 20:249-253. https://doi.org/10.1016/j.ufug.2016.09.008

171. LiY, Wang S, Chen Q (2019) Potential of thirteen urban greening plants to capture particulate matter on leaf surfaces across three levels of ambient atmospheric pollution. Int J Environ Res Public Health. https://doi.org/10. 3390/ijerph16030402

172. Xu Y, Xu W, Mo L, Heal MR, Xu X, Yu X (2018) Quantifying particulate matter accumulated on leaves by 17 species of urban trees in Beijing, China. Environ Sci Pollut Res 25:12545-12556. https://doi.org/10.1007/ s11356-018-1478-4

173. Freer-Smith PH, El-Khatib AA, Taylor G (2004) Capture of particulate pollution by trees: a comparison of species typical of semi-arid areas (Ficus nitida and Eucalyptus globulus) with European and North American species. Water Air Soil Pollut 155:173-187. https://doi.org/10.1023/B:WATE. 0000026521.99552.fd

174. Gawrońska H, Bakera B (2015) Phytoremediation of particulate matter from indoor air by Chlorophytum comosum L. plants. Air Qual Atmos Heal 8:265-272. https://doi.org/10.1007/s11869-014-0285-4

175. Hedblom M, Lindberg F, Vogel E, Wissman J, Ahrné K (2017) Estimating urban lawn cover in space and time: case studies in three Swedish cities. Urban Ecosyst 20:1 109-1119. https://doi.org/10.1007/s11252-017-0658-1

176. Yang F. Rethinking lawns as prevalent elements of urban green spaces; 2019.

177. Fowler D, Skiba U, Nemitz E, Choubedar F, Branford D, Donovan R, Rowland P (2004) Measuring aerosol and heavy metal deposition on urban woodland and grass using inventories of 210PB and metal concentrations in soil. Water Air Soil Pollut Focus 4:483-499. https://doi.org/10. 1023/B:WAFO.0000028373.02470.ba

178. Cowherd C, Grelinger MA, Gebhart DL. Development of an emission reduction term for near-source depletion. In: 15th Int. emiss. invent. conf. "reinventing invent. — new ideas new Orleans". 2006, p. 1-9.

179. Southon GE, Jorgensen A, Dunnett N, Hoyle H, Evans KL (2018) Perceived species-richness in urban green spaces: cues, accuracy and well-being impacts. Landsc Urban Plan 172:1-10. https://doi.org/10.1016/j.landu rbplan.2017.12.002

180. Nizzetto L, Pasture C, Liu X, Camporini P, Stroppiana D, Herbert B, Boschetti M, Zhang G, Brivio PA, Jones KC et al (2008) Accumulation parameters and seasonal trends for PCBs in temperate and boreal forest plant species. Environ Sci Technol 42:5911-5916. https://doi.org/10.1021/ es $800217 \mathrm{~m}$

181. Fellet G, Pošćić F, Licen S, Marchiol L, Musetti R, Tolloi A, Barbieri P, Zerbi $G$ (2016) PAHs accumulation on leaves of six evergreen urban shrubs: A field experiment. Atmos Pollut Res 7:915-924. https://doi.org/10.1016/j. apr.2016.05.007

182. Chatani S, Okumura M, Shimadera H, Yamaji K, Kitayama K, Matsunaga SN (2018) Effects of a detailed vegetation database on simulated meteorological fields, biogenic VOC emissions, and ambient pollutant concentrations over Japan. Atmosphere (Basel). https://doi.org/10.3390/ atmos 9050179

183. Acton WJF, Jud W, Ghirardo A, Wohlfahrt G, Hewitt CN, Taylor JE, Hansel A (2018) The effect of ozone fumigation on the biogenic volatile organic compounds (BVOCs) emitted from Brassica napus above- and belowground. PLoS ONE 13:1-19. https://doi.org/10.1371/journal.pone.02088 25

184. Fitzky AC, Sandén H, Karl T, Fares S, Calfapietra C, Grote R, Saunier A Rewald B (2019) The interplay between ozone and urban vegetationBVOC emissions, ozone deposition, and tree ecophysiology. Front For Glob Chang 2:1-17. https://doi.org/10.3389/ffgc.2019.00050

185. Préndez M, Corada K, Morales J (2013) Biogenic volatile organic compounds from the urban forest of the Metropolitan Region, Chile. Res J Chem Environ 17:108-116. https://doi.org/10.1016/j.envpol.2013.04.003 
186. Varshney CK, Singh AP (2003) Isoprene emission from Indian trees. J Geophys Res Atmos. https://doi.org/10.1029/2003jd003866

187. Mcpherson EG, Nowak DJ, Heisler G, Grimmond S, Souch C, Grant R, Rowntree R (1997) Chicago's urban forest ecosystem: results of the Chicago urban forest climate project. Urban Ecosyst 1:49-61

188. Costanza R, Fisher B, Mulder K, economics, S.L.-E. (2007) undefined Biodiversity and ecosystem services: a multi-scale empirical study of the relationship between species richness and net primary production. Elsevier, Hoboken

189. Schlesinger W (2005) Biogeochemistry. Elsevier, Hoboken

190. Ni J, Zhang XS, Scurlock JMO (2001) Synthesis and analysis of biomass and net primary productivity in Chinese forests. Ann For Sci 58:351384. https://doi.org/10.1051/forest:2001131

191. Díaz S, Cabido M (2001) Vive la différence: plant functional diversity matters to ecosystem processes. Trends Ecol Evol 16:646-655. https:// doi.org/10.1016/S0169-5347(01)02283-2

192. Manes F, Silli V, Salvatori E, Incerti G, Galante G, Fusaro L, Perrino C (2014) Urban ecosystem services: tree diversity and stability of PM10 removal in the metropolitan area of Rome. Ann di Bot 4:19-26. https:// doi.org/10.4462/annbotrm-11746

193. Manes F, Marando F, Capotorti G, Blasi C, Salvatori E, Fusaro L, Ciancarella L, Mircea M, Marchetti M, Chirici G et al (2016) Regulating Ecosystem Services of forests in ten Italian Metropolitan Cities: air quality improvement by PM10 and O3 removal. Ecol Indic 67:425-440. https:// doi.org/10.1016/j.ecolind.2016.03.009

194. Shugart HH, Foster A, Wang B, Druckenbrod D, Ma J, Lerdau M, Saatchi S, Yang X, Yan X (2020) Gap models across micro- to mega-scales of time and space: examples of Tansley's ecosystem concept. For Ecosyst. https://doi.org/10.1186/s40663-020-00225-4

195. Barwise $Y$, Kumar $P$ (2020) Designing vegetation barriers for urban air pollution abatement: a practical review for appropriate plant species selection. NPJ Clim Atmos Sci 3:1-19. https://doi.org/10.1038/ s41612-020-0115-3

196. Doran PM (2009) Application of plant tissue cultures in phytoremediation research: incentives and limitations. Biotechnol Bioeng 103:60-76. https://doi.org/10.1002/bit.22280

197. Rylott EL, Johnston EJ, Bruce NC (2015) Harnessing microbial gene pools to remediate persistent organic pollutants using genetically modified plants—a viable technology? J Exp Bot 66:6519-6533. https:// doi.org/10.1093/jxb/erv384

198. Dhankher OP, Pilon-Smits EAH, Meagher RB, Doty S (2012) Biotechnological approaches for phytoremediation. Plant Biotechnol Agric https://doi.org/10.1016/B978-0-12-381466-1.00020-1

199. Rai PK, Kim KH, Lee SS, Lee JH (2020) Molecular mechanisms in phytoremediation of environmental contaminants and prospects of engineered transgenic plants/microbes. Sci Total Environ. https://doi. org/10.1016/j.scitotenv.2019.135858

200. Doty SL, James CA, Moore AL, Vajzovic A, Singleton GL, Ma C, Khan Z, Xin G, Jun WK, Jin YP et al (2007) Enhanced phytoremediation of volatile environmental pollutants with transgenic trees. Proc Natl Acad Sci U S A 104:16816-16821. https://doi.org/10.1073/pnas.0703276104

201. Yadav R, Arora P, Kumar S, Chaudhury A (2010) Perspectives for genetic engineering of poplars for enhanced phytoremediation abilities. Ecotoxicology 19:1574-1588. https://doi.org/10.1007/s10646-010-0543-7

202. Akbari H, Cartalis C, Kolokotsa D, Muscio A, Pisello AL, Rossi F, Santamouris M, Synnefa A, Wong NH, Zinzi M (2016) Local climate change and urban heat island mitigation techniques - the state of the art. J Civ Eng Manag 22:1-16. https://doi.org/10.3846/13923730.2015.1111934

203. Roviello V, Roviello GN (2021) Lower COVID-19 mortality in Italian forested areas suggests immunoprotection by Mediterranean plants. Environ Chem Lett 19:699-710. https://doi.org/10.1007/ s10311-020-01063-0

204. Santamouris M, Ban-Weiss G, Osmond P, Paolini R, Synnefa A, Cartalis C, Muscio A, Zinzi M, Morakinyo TE, Ng E et al (2018) Progress in urban greenery mitigation science-assessment methodologies advanced technologies and impact on cities. J Civ Eng Manag 24:638-671. https://doi.org/10.3846/jcem.2018.6604
205. De Kempeneer L, Sercu B, Vanbrabant W, Van Langenhove H, Verstraete W (2004) Bioaugmentation of the phyllosphere for the removal of toluene from indoor air. Appl Microbiol Biotechnol 64:284-288. https:// doi.org/10.1007/s00253-003-1415-3

206. Schreck E, Foucault Y, Sarret G, Sobanska S, Cécillon L, Castrec-Rouelle M, Uzu G, Dumat C (2012) Metal and metalloid foliar uptake by various plant species exposed to atmospheric industrial fallout: Mechanisms involved for lead. Sci Total Environ 427-428:253-262. https://doi.org/10. 1016/j.scitotenv.2012.03.051

207. Uzu G, Schreck E, Xiong T, Macouin M, Lévêque T, Fayomi B, Dumat C (2014) Urban market gardening in Africa: foliar uptake of metal(loid)s and their bioaccessibility in vegetables; implications in terms of health risks. Water Air Soil Pollut. https://doi.org/10.1007/s11270-014-2185-5

208. Romero-Estévez D, Yánez-Jácome GS, Simbaña-Farinango K, VélezTerreros PY, Navarrete H (2020) Determination of cadmium and lead in tomato (Solanum lycopersicum) and lettuce (Lactuca sativa) consumed in Quito, Ecuador. Toxicol Rep 7:893-899. https://doi.org/10.1016/j. toxrep.2020.07.008

209. Säumel I, Kotsyuk I, Hölscher M, Lenkereit C, Weber F, Kowarik I (2012) How healthy is urban horticulture in high traffic areas? Trace metal concentrations in vegetable crops from plantings within inner city neighbourhoods in Berlin, Germany. Proc Environ Pollut 165:124-132

210. Li Y, Wang H, Wang H, Yin F, Yang X, Hu Y (2014) Heavy metal pollution in vegetables grown in the vicinity of a multi-metal mining area in Gejiu, China: total concentrations, speciation analysis, and health risk. Environ Sci Pollut Res 21:12569-12582. https://doi.org/10.1007/ s11356-014-3188-x

211. De Temmerman L, Ruttens A, Waegeneers N (2012) Impact of atmospheric deposition of $\mathrm{As}, \mathrm{Cd}$ and $\mathrm{Pb}$ on their concentration in carrot and celeriac. Environ Pollut 166:187-195. https://doi.org/10.1016/j.envpol. 2012.03.032

212. El-Khatib AA, Abd El-Rahman AM, Elsheikh OM (2011) Leaf geometric design of urban trees: potentiality to capture airborne particle pollutants. J Environ Stud 7:49-59

213. Das S, Prasad P (2010) Seasonal variation in air pollution tolerance indices and selection of plant species for industrial areas of rourkela. Indian J Environ Prot 30:978-988

214. Popek R, Haynes A, Przybysz A, Robinson SA (2019) How much doesweather matter? Effects of Rain and Wind on PM accumulation by four species of Australian Native Trees. Atmosphere (Basel) 10:1-14. https:// doi.org/10.3390/atmos10100633

215. Kończak B, Cempa M, Pierzchała A, Deska M (2021) Assessment of the ability of roadside vegetation to remove particulate matter from the urban air. Environ Pollut 268:115465. https://doi.org/10.1016/j.envpol. 2020.115465

\section{Publisher's Note}

Springer Nature remains neutral with regard to jurisdictional claims in published maps and institutional affiliations.

\section{Submit your manuscript to a SpringerOpen ${ }^{\circ}$ journal and benefit from:}

- Convenient online submission

- Rigorous peer review

- Open access: articles freely available online

- High visibility within the field

- Retaining the copyright to your article

Submit your next manuscript at $\boldsymbol{\nabla}$ springeropen.com 